University of Rhode Island

DigitalCommons@URI

Open Access Dissertations

1992

\title{
Out of the Shadows: A Structuralist Approach to Understanding the Fiction of H. P. Lovecraft
}

James A. Anderson

University of Rhode Island

Follow this and additional works at: https://digitalcommons.uri.edu/oa_diss

\section{Recommended Citation}

Anderson, James A., "Out of the Shadows: A Structuralist Approach to Understanding the Fiction of H. P. Lovecraft" (1992). Open Access Dissertations. Paper 696.

https://digitalcommons.uri.edu/oa_diss/696

This Dissertation is brought to you for free and open access by DigitalCommons@URI. It has been accepted for inclusion in Open Access Dissertations by an authorized administrator of DigitalCommons@URI. For more information, please contact digitalcommons-group@uri.edu. 


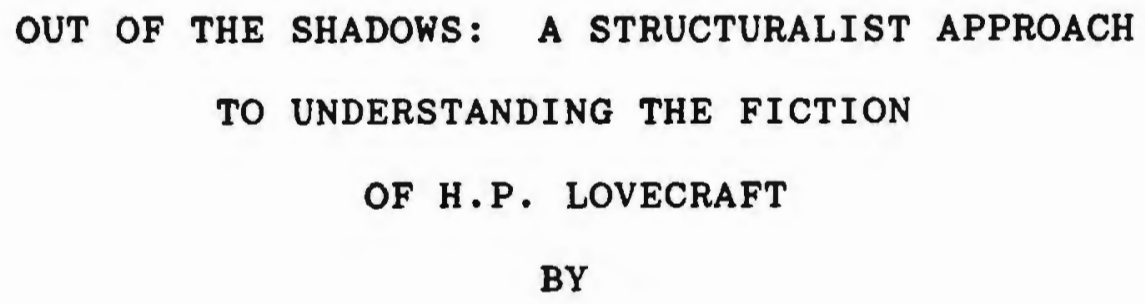

A DISSERTATION SUBMITTED IN PARTIAL FULFILLMENT OF THE REQUIREMENTS FOR THE DEGREE OF DOCTOR OF PHILOSOPHY

IN

ENGLISH 


\section{Abstract}

Although Howard Phillips Lovecraft $(1890-1937)$ is generally regarded as one of the world's finest writers of horror and science fiction, his work has received little critical attention by mainstream critics. This study takes Lovecraft out of the shadows of literature by shedding light upon his work through a structural analysis of fifteen of his stories. This analysis shows that Lovecraft's fiction, while it may appear fantastic, expresses early twentieth century naturalism in a cosmic context.

Part One subjects four of Lovecraft's best known stories to a detailed structural analysis using the theories of Roland Barthes and Gerard Genette to isolate Lovecraft's major themes and narrative techniques. Part Two defines the horror genre as Lovecraft saw it and explores his unique combination of science fiction and the weird tale, which has created a new kind of folktale based upon scientific mythology. Finally, Part Three explores Lovecraft's vision of truth, and how he employs fantasy as a means of understanding reality.

The dissertation concludes with an evaluation of Lovecraft in relation to the canon of twentieth century American literature, and explains how his writing runs counter to the type of work privliged by modern critics. The structuralist approach demonstrates that much of what 
are mistakenly perceived to be flaws in Lovecraft's work are really essential components of his overall theme and meaning . 


\section{ACKNOWLEDGEMENTS}

I would like to acknowledge the dedicated efforts of S.T. Joshi for setting the standards for Lovecraft scholarship and for his leadership as a critic and editor. I would also like to thank Mark A. Michaud, publisher of Necronomican Press and Lovecraft Studies, and Jon B. Cooke, editor of Tekeli-li Journal of Terror for supporting Lovecraft criticism in their publications. Finally, I would like to thank my colleagues at Johnson \& Wales University for the assistance and support they have given me. 
TABLE OF CONTENTS

ACKNOWLEDGEMENTS . . . . . . . . . . . . . . iv

INTRODUCTION . . . . . . . . . . . . . . 1

PART ONE: INTERPRETING THE SHADOWS. . . . . . . 7

1. INTO THE SHADOWS: "THE SHADOW OVER INNSMOUTH" - 13

2. "PICKMAN'S MODEL": LOVECRAFT'S MODEL OF TERROR. - 20

3. "THE CALL OF CTHULHU": FLAGSHiP OF THE MYTHOS . 39

4. "Rats in the walls": Narrative DeVices. . . . . 51

PART TWO: LOVECRAFT'S VISION OF HORROR. . . . . . . 61

5. "DAGON": FUNDAMENTAL LOVECRAFT. . • . . . . . 64

6. "THE SHUNNED HOUSE": THE IRONY OF HORROR. . . . . 74

7. "THE COLOUR OUT OF SPACE": COSMIC HORROR DEFINED. 80

8. "THE DUNWICH HORROR": THE MYTHOLOGY OF FEAR . . 86

9. "THE UNNAMABle": THE POWER OF LANGUAGE. . . . . 100

PART THREE: LOVECRAFT'S VISION OF TRUTH: FANTASY AS

A MEANS OF UNDERSTANDING REALITY . . . . . . 107

10. CHARLES DEXTER WARD: PROTOTYPE PROTAGONIST. • . 110

11. "THE OUTSIDER": THE TERROR WITHIN . . . . . . . 121

12. "FROM BEYOND" BREAKING DOWN THE BARRIERS. . . . 129

13. "THE HAUNTER IN THE DARK": CULTURAL CODE IN THE TWO HILLS OF PROVIDENCE. . . . . . . . . . . . 138

14. "THE WHISPERER IN DARKNESS": THE SEDUCTIVE POWER OF KNOWLEDGE . . . . . . . . . . . . . . . . . . 144

15. "THE SHADOW OUT OF TIME": OUT OF THE SHADOWS . . 153 CONCLUSION. • . • . . . . . . . . . . . 161 LOVECRAFT'S INFLUENCE OF HORROR LOVECRAFT'S USE OF HORROR AS A METAPHOR LOVECRAFT'S PLACE IN AMERICAN LITERATURE

IN DEFENSE OF H.P. LOVECRAFT 
TO MY PARENTS

AND

TO PATRICIA 
INTRODUCTION 
Although Howard Phillips Lovecraft (1890-1937) is generally recognized as one of the world's finest writers of horror and science fiction, his work has received little critical attention outside of the genres to which it has conveniently been categorized. While some excellent critical work has been accomplished in Lovecraft studies, it has, for the most part, been written by dedicated amateurs and fans rather than by mainstream scholars and critics who tend to avoid the genre-type work of Lovecraft and his peers (Cannon, 24). As a result, the study of Lovecraft has been forced into the shadows of literary criticism, where it has become more closely associated with science fiction and horror than with the study of more privileged kinds of literature.

There are, in fact, many who would say that Lovecraft should remain in the shadows, that his work is strictly hack writing designed for the pulp magazines of his time. Critics such as Edmund Wilson have ridiculed Lovecraft's "concocted myth" (47) and fantastic ideas, while praising the realistic work of his contemporaries (Hemingway, Dos Passos, and others). And even today, Lovecraft is seldom represented in mainstream anthologies of short fiction or American literature, and is generally not taught as part of twentieth century American literature. This, $I$ believe, is because Lovecraft has yet to be fully understood and 
appreciated by mainstream critics, who see him only as a writer of the "weird tale."

Yet, even as Lovecraft is dismissed or ignored by mainstream critics, he has still endured, becoming more popular after his death than he ever was during his lifetime. Although his work was never published in book form while he lived, all of his fiction remains in print today, both in the Arkham House hardcover editions (revised by S.T. Joshi to be as textually accurate as possible), and in mass market paperback editions. Furthermore, Lovecraft remains one of the most widely anthologized authors in the horror and science fiction genres. Thus, despite the lack of scholarly attention to his work, H.P. Lovecraft refuses to go away.

In my study, I will attempt to take Lovecraft out of the shadows of literature and into the light of critical theory as I analyze his works as mainstream stories. Using a structuralist critical theory as my underlying method, my analysis will show that Lovecraft's work expresses many of the realistic themes of his contemporaries. While his stories may appear fantastic, they are based upon naturalism, which Lovecraft takes to the N'th degree through a cosmic context. While Hemingway's world might be cruel and unforgiving, individual characters can, at least, leave some mark upon the world. In Lovecraft's universe, however, the individual is but a flea, incapable of even understanding the world, let alone influencing it. 
Lovecraft deviates from his peers by using fantastic devices to express realistic themes. This technique allows him to expand the universe beyond the limits found in traditional fiction in order to show man's relationship to the infinite cosmos. His combination of science fiction with horror has created the concept of "cosmic horror," a far more depressing and pessimistic view than naturalism. Lovecraft, who believed in man's fundamental triviality, expressed this philosophy through fantasy and science fiction, the most logical and effective devices with which to depict human cosmic insignificance.

In taking Lovecraft out of the shadows, I will use structuralist critical theory as my underlying method to shed light on the major themes and narrative devices of his work. Yet, unlike traditional structuralist studies, mine will use an eclectic approach designed to illuminate the meaning of the fiction rather than produce an essay on structuralist technique. This approach will use a number of theories, including those of Roland Barthes $(\underline{S / Z})$, Gerard Genette, Robert Scholes, Claude Levi-Strauss, and others as needed. Where appropriate, I will also utilize traditional critical methods, observations of other Lovecraft scholars, and Lovecraft's own theories about fiction and literature as revealed in his letters and nonfictional writings.

I realize that these methods were never intended to be used for the purposes of explication to which I will put 
them. A "pure" structuralist would never approve of my interpretive technique; however, I feel that these various techniques "complement one another in addressing the fictional text from different angles" (Scholes, semiotics 87) and that they can be an effective form of textual analysis. I will freely adapt these methods as needed in analyzing each particular story to achieve my goal of understanding Lovecraft's fiction.

Perhaps the most difficult part of my work has involved choosing the specific stories for analysis, and I must confess that my choices are partly based upon personal preference. I have tried to achieve a representative mix of stories, including some of Lovecraft's early work, as well as his later and best known stories. In each of these stories I have attempted to highlight certain themes and/or techniques through a variety of structuralist and other critical methods.

Rather than analyze the stories cinronologically, I have arranged my analysis in three parts. Part One examines four of Lovecraft's most well-known and widely reprinted stories in depth using structuralist methodology. I begin my discussion with "The Shadow Over Innsmouth," where I take the reader "into the shadows" and introduce Lovecraft's major themes and techniques; the remaining analyses in this section are more scientific and "pure" structuralist, utilizing the theories of Roland Barthes and Gerard Genette. 
Part Two defines the horror genre as Lovecraft saw it, explores Lovecraft's unique vision of the weird tale, and shows where his vision fits within the genres of horror and science fiction and within mainstream literature. Finally, Part Three explores Lovecraft's vision of truth, and shows how he expressed this vision through the devices of horror and science fiction. This section, in particular, will attempt to take Lovecraft's fiction out of the shadows through the light of scholarly criticism, where Lovecraft can be evaluated as a writer of fiction, rather than merely a producer of "weird tales."

The application of mainstream critical theory to these selected stories will demonstrate that Lovecraft was, indeed, a realist, and that his stories present a distinct and relevant view of the universe, a view that takes naturalism to the farthest limits of the cosmos. 
PART ONE

INTERPRETING THE SHADOWS 
PART ONE

Interpreting the Shadows

As I have stated in the introduction, Part one of this work will examine several Lovecraft stories in great detail using a structuralist methodology. I have chosen to analyze the stories using this theory for several reasons. First, structuralists have always been attracted to popular literature. Early structuralist critics such as vladimir Propp and Claude Levi-Strauss examined myths and folktales; later structuralists studied detective stories (Todorov, Poetics 42-52) as well as science fiction (Scholes) and the literature of the fantastic (Todorov), stories which, I feel, represent the mythology of the twentieth century. Popular fiction represents the thoughts and ideas of the culture which produces it, and structuralism defines itself in part as cultural analysis that "seeks to explore the relationship between the system of literature and the culture of which it is a part" (Scholes, Structuralism 11). Secondly, Lovecraft's stories make good material for a structuralist reading because they are short, narrative pieces with a definite plot structure. Traditional formalist techniques concentrate more on theme than method, while structuralists such as Gerard Genette and Seymour Chatman have developed a science of narratology. 
Thisapproach to how a story works, in addition to what it actually says, seems most appropriate in examining an author who primarily wrote for the pulp magazines of his time.

The first of my methods, the theory of Gerard Genette, distinguishes between narrative and discourse. The narrative, or "story," includes the basic sequence of events that occurs in the text, while the discourse refers to the manner in which the author tells the story. This method involves the examination of narrative voice, time reference and frequency, and the pace of the actual events in the story. The critic looks at narrative voice in order to determine who narrates the story and through whose point of view the events are seen. This structuralist study goes beyond mere "point of view" to determine how and why a narrative may subtly shift from one focus character to another. The critic examines time reference and frequency to isolate the present of the narrative from the past, as shown in flashbacks, and from the future, as shown in foreshadowings and predictions. Finally, the critic looks at the speed with which the discourse moves through the sequence of events in the story.

The second critical method is that of Roland Barthes as outlined in $\mathrm{s} / \mathrm{Z}$. In this work, Barthes examines a text by breaking it down into a series of "codes" common to all literature. Barthes claims that in order to comprehend anything, be it a work of literature, a piece of music, or 
an advertisement on television, the human mind must interpret it through fixed codes of understanding. Language itself represents such a code; unless one understands the "code" of English, for example, discourse in the language becomes meaningless. According to Barthes, there are six basic codes of understanding in any artistic work. These are the proairetic code (or code of action), the hermeneutic code (or code of enigmas), the cultural code, the connotative code, the symbolic code, and the textual code. An additional code, the psychoanalytical code, can be thought of as a specialized form of the symbolic code.

The first two codes, the action code and the hermeneutic code, work together to define the narrative elements that distinguish the story from the discourse, and complement the theories of Gerard Genette. The action code traces the actual physical movement of the action in the narrative, while the hermeneutic code reveals the series of questions or puzzles that the author uses to create suspense in the text. The reader desires the answers to these puzzles, yet the author withholds them until the last possible moment. This code is especially important in popular fiction-- indeed, the detective story finds its sole raison d'etre in the code of enigmas.

The next three codes, the cultural, connotative, and symbolic codes, work together to create character, enhance meaning, and determine theme in a literary work. The 
cultural code can be used to examine the literary work's explicit and implicit references to the culture in which it was written. According to Barthes, no literary work can be entirely divorced from the culture that produced it. Understanding this code may expose themes and meanings deemed important by that particular culture. The connotative code schematizes the dominant connotations of the text's language in regard to character and setting. This code often develops characters in traditional stories, and, in Lovecraft's work contributes greatly to the overall mood of terror that the author tried to produce. Finally, the symbolic code assumes that meaning occurs through symbolic binary oppositions which create theme through their conflict. The psychoanalytical code, for example, is a specialized symbolic code based on Freud's theories.

Barthes' textual code, or metalinguistic code, shows the use of a metalanguage when "one speaks about what one is going to say" ("Valdemar" 139). "One can loosely define this textual code as existing whenever a written work speaks about itself, or of the writing of the text itself, or of writing and/or communicating in general. The textual code often exposes themes dealing with writing and communication.

Barthes uses his codes to interpret specific literary works ( $S / Z$, "Valdemar") by dividing the text into random units which he terms "lexias" ( $\underline{s / z} 13)$ and picking the codes out of each fragmented section. For purposes of my 
analysis, however, I will not fragment the text, but will demonstrate how the various codes weave their way through the work as a whole.

I intend to use the perspectives of Genette coupled with Barthes' hermeneutic and action codes to show how Lovecraft has structured his stories to create and maintain suspense while keeping the story moving towards its conclusion. Using Barthes' connotative code I will show how Lovecraft created terror through language and mood. And by employing Barthes' cultural, symbolic, and textual codes I will examine Lovecraft's major themes of cosmic horror, and the destructive nature of truth-- particularly artistic truth. I will also use the textual code to shed some insight into the nature of horror and the weird tale as perceived by its acknowledged master, H.P. Lovecraft.

It is my hope that applying a specific literary theory to the fiction of H.P. Lovecraft will demonstrate that his stories are much more complex than first appearances might indicate, and that a detailed textual analysis can prove fruitful. I believe that such theoretical approach will help to bring Lovecraft out of the shadows of literature and to the attention of mainstream literary critics. 


\section{Into the Shadows: \\ "The Shadow Over Innsmouth"}

Donald Burleson, in his deconstructive analysis of "The Shadow over Innsmouth" notes that "A shadow is a problematic entity from the outset" (Disturbing 135). The shadow, he says, confuses the nature of absence and presence by marking presence with absence, causing the two concepts to mingle.

The fictional work of H.P. Lovecraft, like the shadow, is a problematic entity in many ways. By bringing us into the symbolic shadows of horror, Lovecraft establishes the presence of what he termed the "weird tale", which, almost by definition, explores the impossible and the fantastic. Yet while this shadow may signify an absence of realism through its presence, it also signifies the presence of realism somewhere, for the realistic object must ultimately cast the shadow. Thus, Lovecraft's works, even at their most fantastic, hint at the realistic horrors which cast the shadows. The shadow, the fantastic, is the device which captures the true, realistic vision of horror. And, according to Lovecraft, this horror derives from science, nature and knowledge rather than from the supernatural. As Gafford has noted, "The Shadow out of Innsmouth" is 
the story where "Lovecraft puts everything together.... In no other story would Lovecraft combine so many of his favorite themes and concepts" (6). The comprehensiveness of this story, coupled with Joshi's observation that it is "... considerably more subtle and carefully worked out and is one of [Lovecraft's] greatest stories" (Weird Tale 223 ) makes "The Shadow over Innsmouth" an excellent point in which to begin "interpreting the shadows." Therefore, I will use this story as brief introduction to Lovecraft's major themes and ideas; the detailed structural analyses that complete Part One will develop these ideas further and examine how they are revealed within the individual texts. While some critics (most notably L. Sprague deCamp) have seen Lovecraft in general and "The Shadow over Innsmouth" in particular as little more than "a good, rousing yarn" (354), a critical reading of the tale reveals its allegorical nature and a number of complex themes. As the narrator of "Shadow" says in a "textual code" of his own: "The insane yarn $I$ was hearing interested me profoundly, for I fancied there was contained within it a sort of crude allegory." (DH 334) As Gatto has demonstrated, this statement is a textual reference to the story itself, although, in reality, the allegory "is far from crude" (76).

"The Shadow over Innsmouth" enumerates several major Lovecraft themes that will reappear as we examine other stories in greater detail. As an overview to Lovecraft's 
fiction, I will speak briefly about each of these themes and their significance in other works.

First and foremost, one cannot overlook the prevailing influence of the "Cthulhu Mythos" (or what has come to be known as simply as "The Mythos" or "the myth-cycle") on both "The Shadow over Innsmouth" and on Lovecraft's fiction in general. This Mythos concept postulates the existence of a pantheon of alien beings who came to earth during prehistory and still inhabit isolated pockets of the world. These aliens appear or are alluded to throughout the myth cycle.

According to Lawrence Lynn, the Cthulhu creatures can fundamentally be divided into two groups: those who come from some distant point in known space, including the Elder Things, Outer Ones, and Deep Ones; and a second group that comes from somewhere beyond the known frame of space and time, including the Great Race, Great old Ones, and the Mi-go (15). The most complete single history of the Cthulhu beings is presented in At The Mountains of Madness (see especially pages 61-77), which details the wars between the old Ones and the Spawn of Cthulhu, the old Ones and the Shoggoths, and the creation of life on earth. This essential background forms the basis for the myth-cycle as a whole.

The Mythos is probably the most misunderstood concept in the Lovecraft canon for several reasons. First, a host of authors ranging from extremely talented to hopelessly 
inept have eagerly taken the mythos and adapted it into their own creations, thereby blurring the lines between Lovecraft's inventions and their own. Secondly, as Richard L. Tierney has asserted, the "Cthulhu Mythos" is actually a creation of August Derleth, rather than Lovecraft. Derleth, in his attempts to make the mythos stories fit the traditional pattern of good and evil, probably did more to set back Lovecraft studies than even Lovecraft's harshest critics could do.

As Robert M. Price says, and rightly so, Lovecraft did not intend the mythos to be complete in and of itself, but intentionally left loose ends and inconsistencies: "...he was trying to create the same kind of inconsistency one sees in any ancient legend-cycle..." (16). What have been called inconsistencies in "The Shadow over Innsmouth" and in other stories are merely part of Lovecraft's overall plan.

"The Shadow over Innsmouth," as Gafford has stated, may be considered an extension of the mythos history presented in At the Mountains of Madness (7), and makes the connection between the Spawn of Cthulhu as ancestors of the Deep Ones, and defines Dagon as a Deep One himself.

As Gafford has pointed out, "Lovecraft used the mythos as a literary tool" (8) and not as an end in itself, and the Deep Ones are the "least important" part of the story. The myth-cycle of Lovecraft, like Faulkner's Yoknapatawpha County, provides a consistent and convincing setting upon 
which to build narrative, and allows each tale within the mythos to enrich each other story through minor allusions that create complete images. In Lovecraft's world, Arkham Massachusetts is as real as Jefferson Mississippi, and Miskatonic University as concrete as Sutpen's Hundred. The second major theme of "The Shadow over Innsmouth" concerns heredity and what Gafford calls "Hereditary Memory" (11) -- the "reversion to the habits, customs, and styles of ancestors." This idea of reverse evolution can be found in a number of Lovecraft stories: "Pickman's Model", "The Rats in the Walls", The Case of Charles Dexter Ward, and others. According to this idea, pockets of humanity have interbred with monsters to form new and degenerate life forms, such as the inhabitants of Innsmouth. This type of story has an otherwise normal protagonist learning that he is a descendent of this degenerate race and reverting to his primitive form. While a more traditional author would rely on this knowledge alone as the main ingredient of horror, Lovecraft takes the idea one step further. As Joshi has shown, the significance of the story is not in the narrator's learning of his ancestry, but in his accepting and welcoming it (Weird Tale 224 ).

The third major theme, and a corollary to the theme of heredity in the case of "The shadow over Innsmouth", involves the quest for truth by a protagonist and the resulting destruction that discovery of that truth brings. 
This theme appears in virtually every major story and, along with the mythos and the theme of man's insignificance in the universe (which will be discussed next), is a distinctive Lovecraft trademark. In "The Shadow Over Innsmouth" the narrator discovers that he, too, has the "Innsmouth look" and is in fact a product of a degenerate race. Although the nature of the search may vary from genealogy in "The Shadow over Innsmouth" and Charles Dexter Ward to scientific curiosity in "The Reanimator" and Mountains of Madness, the result is always the same: the discovery of forbidden knowledge leads to madness, destruction, and pain. Although Lovecraft scholars have speculated upon the autobiographical nature of this theme in relation to the history of insanity that ran through Lovecraft's own ancestry, it is obvious from Lovecraft's letters that his personal search for truth resulted in the belief in the insignificance of man in the universe, a philosophy that brought him great personal pain.

Finally "The Shadow over Innsmouth" highlights this theme of man's insignificance, a perception that Lovecraft gained through his extensive interest in astronomy and science. In this story the universe is symbolized by the ocean, a cold, dark region similar to the cosmos itself and harboring deep and terrible mysteries. This theme is the by-product of the myth-cycle, which is specifically designed to highlight man's inferiority and unimportance in the universe. Or, as Lynn has said: "Lovecraft was among 
the earliest Science Fiction writers to fully appreciate the existential significance of Copernicus. The earth is not the center of the universe, hence, neither is man."

To read Lovecraft is to enter into the shadows, to explore the forbidden worlds of the "dreaded Necronomican" and to discover that man is little more than a microbe in a cosmic Petri dish. Lovecraft brings us into these shadows and shows us things we may not wish to see, for hidden away in his fantastic, impossible worlds there lurks a realistic, scientific view of the universe in which we live. 'It is a cold, unforgiving view of cosmos guided strictly by natural laws, with no hope of a deity or of salvation. In Lovecraft's world, even man himself is a mistake, a byproduct of alien genetic engineering gone wrong. It is not the happy-ending fantasy world of Tolkein's Hobbits or the Mars men of Edgar Rice Burroughs, but rather the naturalism of a Hemingway taken to the $\mathrm{N}-\mathrm{th}$ degree. 


\section{2. "Pickman's Model":}

Lovecraft's Model of Terror

Since "Pickman's Model" is one of Lovecraft's most famous and most widely reprinted stories, and, with its theme of underground horror is representative of his technique and style, I will begin my analysis with a stucturalist reading of this tale based upon the theories of Genette and Barthes, adapted to my own uses. This analysis will create a "model" of Lovecraft by isolating certain themes and techniques which reoccur throughout his fiction.

Most short stories do not begin at the beginning, but begin somewhere toward the end, then fill in the beginning with flashbacks, or analepses in structuralist terminology, which Genette defines as "any evocation after the fact of an event that took place earlier than the point in the story where we are at any given moment" (Narrative $40)$.

Strictly speaking, the "story" of "Pickman's Model" begins at some undetermined time in the past when the narrator "got into the habit of calling on Pickman quite often" (DH 14). The discourse, however, begins with the narrator explaining to Eliot why he is afraid of the 
subway. The story, in essence, is already over and is about to be retold by the narrator.

The discourse provides needed background through analepses. For example, Lovecraft fills in some of the background material in his conversation with Eliot (13), as he tells of Pickman's mysterious disappearance. In the next several pages, he fills in additional background information like pieces of a puzzle. We learn about Pickman's bizarre art and the narrator's relationship with the artist and then we learn that Pickman's genealogy includes a history of witchcraft dating back to the Salem witch trials. This information, presented almost off-handedly, becomes important only in retrospect as the surprise ending of the story is revealed.

These analepses are used for two distinct purposes. First, they efficiently fill in needed background information, detail and character development in an interesting and economical manner. Secondly, the analepses provide "clues" to the story's resolution. Thus, Pickman's "unnatural" family history turns out to be an important factor in the story's ending, as does his propensity toward the grotesque. In retrospect, these subtle clues enable the reader to draw his own conclusions about Pickman's fate.

Many popular short stories in the horror and science fiction genres depend upon a surprise or unusual ending for their mass appeal. Yet the ending cannot be too much of a 
surprise-- enough clues must be planted so that the reader can understand how the "surprise" came about. Otherwise the reader feels cheated, feels that the author has not been playing fair, since there was no possibility of anticipating the ending. The prolepsis, or foreshadowing device, plants clues within the narrative. Some of these clues, as we have seen, may be analepses, events from the past that take on significance in the future. Other clues will not be related to the past.

"Pickman's Model" contains a number of prolepses that foreshadow the tale's outcome. For example, the narrator's fear of the subway forshadows his horrible experience in Pickman's underground studio ( $\mathrm{DH} 12)$. He goes on to talk of the "inside information" he had when he dropped him, "and that's why I don't want to think where he's gone." The narrator speaks of Pickman's artistic ability to capture realism (13), and foreshadows the ending with the line "If I had ever seen what Pickman saw-- but no.....Gad, I wouldn't be alive if 'I'd seen what that man-- if he was a man-- saw!"

The foregrounding of the analepses and prolepses as part of the discourse helps the critic see how an author creates suspense by beginning his plot at a crucial point, then sprinkling clues throughout the narrative which anticipate the ending. A look at the hermeneutic code offers a slightly different viewpoint on how an author creates suspense by presenting a series of puzzles and 
enigmas that intrigue the reader, yet keep him wondering about the story's outcome. Some enigmas are explained early in the text, as they are essential to an understanding of the story. Others are not resolved until the very end.

"Pickman's Model," like many successful horror stories, begins with an enigma in the very first line: "You needn't think I'm crazy, Eliot-- plenty of others have queerer prejudices than this." The reader, of course, wonders why the narrator is considered crazy, and what he is afraid of. The answer to the enigma, a partial one, is given in the third sentence-- that he is afraid of the subway. But this only leads to the next question, why? The answer to this enigma, of course, comes at the very conclusion of the story; meanwhile, the reader's interest has been sustained by the desire to learn the answer to this puzzle.

Other enigmas follow: why the narrator has become nervous; why he has dropped Pickman; and what has become of Pickman. Lovecraft carefully sustains the suspense by teasing the reader, leading him on to find the answers. The narrator has "inside information" but he is not about to play his hand too quickly. "I'm coming to that," he explains, as if to assure the reader that he will provide answers, but in his own time and by his own method. The action code details the action of the story-- how the plot actually moves from beginning to end. In this 
respect, it resembles Genette's distinction between story and discourse. I will go one step further, however, and also examine the physical situation of the action-- how, when, and where it occurs. Applying this methodology to "Pickman's Model" reveals an interesting movement of action from light to dark, from modern to old, and from above to below ground. Furthermore, examining the tale through the perspective of the action code calls attention to the actions of the narrator as he tells the tale.

Perhaps the most obvious movement of the action is from light to darkness. Darkness is probably the oldest motif of the tale of terror, reflecting mankind's instinctive fear of the dark and of the unknown. Yet Lovecraft's use of darkness is more interesting and original than the typical haunted house stories that have for so long defined the horror story. In fact, Lovecraft shows the duality of darkness. Of course it is frightening. Yet at the same time it is somehow fascinating. The action begins in daylight, then Pickman leads the narrator through an alley with a dim light to an alley with no light at all. These alleys, in addition to growing darker, become progressively narrower. Once they enter the apartment, Pickman lights an oil lamp so the narrator can gaze upon his etchings.

As they descend into the basement, Pickman uses a flashlight. In the studio itself, "an acetylene gas outfit gave the light necessary for work" (22). 
One infers that Pickman, though he prefers an unnatural light, would really rather have complete darkness for his work. Only the necessity of light compels him to provide for it at all. "I don't want daylight for what I do," he says. "I paint in the cellar, where inspiration is thickest...." (17).

For Pickman, in fact, darkness represents creativity, the dark, half-mad part of his brain that allows him to create. For most people, this part of the mind is off limits. It remains dark and unexplored. Pickman, the true artist, is not content to let that part of his mind remain unexplored, however. To him, this darkness represents an untapped source of creativity.

The camera, also, becomes an image of light, since it, in essence, captures light (or the absence of it) and holds it prisoner. The camera, then, captures the darkness within Pickman's mind, the horrible nameless beings that mankind cannot comprehend or imagine, and makes them real, just as Pickman attempts to do with his painting. Pickman's art represents the imagination, since he recreates an image in artistic form, a shadow of realism. Although his paintings may be horrible and unpalatable to society, they, at least, can be dismissed as the insane work of a madman (and the artist figure has long been associated with madness). The camera and resulting photograph, however, upset this idea by proving that Pickman is, indeed, not really mad-- his vision of reality 
is verified as true by the camera, which captures and holds reality even as a shadow reflects the image of the object creating it.

Pickman, then, perceives truth, which he has discovered in the dark reaches of a forbidden basement as well as in the dark reaches of his mind. Society, by refusing to enter or even consider this world of shadows, has failed to see truth.

If darkness represents artistic truth, it is only natural that it should be feared, for truth is often not only painful, but often disgusting, loathesome, morbid and downright ugly. True artists like Pickman, with his "profound insight into Nature," have found truth in the darkest of places, and "he manages to turn out results that differ from the pretender's mince-pie dreams in just about the same way that the life painter's results differ from the concoctions of a correspondence-school cartoonist" (14).

The action, in addition to moving from light to darkness, also moves from above ground to below ground. The subterranean world of which Pickman is a part also represents artistic truth, since the farther one goes underground, the closer one gets to truth. Pickman, who goes one level lower than the narrator, confronts truth directly in the form of the grotesque monster, while the narrator only sees this truth second hand-- first through Pickman's paintings, and then in the photograph itself. 
The narrator's fear of subways-- or anything underground, for that matter-- is based upon his fear of confronting this truth again, especially in a direct form. He has learned the true nature of the universe, has accepted this truth and even attempts to convey it to Eliot (and to the reader of the story), yet he is unwilling to experience it again.

Not only was this truth painful, grotesque, and disgusting, but it was also destructive, in that it consumed human lives and undoubtedly led to the destruction (or, more probably, conversion) of Pickman himself. The narrator fears that he, too, may become consumed, a fear that is quite justified if one takes into account his fascination with Pickman's model. "Gad, I wouldn't be alive if I'd seen what that man - if he was a man - saw!" (14).

Finally, the action moves from the modern to the ancient, as Pickman leads the narrator into the oldest part of the city. Truth, then, often lies in the past, in Lovecraft's fiction. "It's my business to catch the overtones of the soul," says Pickman, "and you won't find those in a parvenu set of artificial streets on made land" (15). "I tell you, people knew how to live, and how to enlarge to bounds of life, in the old time!" (16)

The narrator has discovered a new reality, a new truth that exists in the deep, dark, ancient reaches, in the shadows that most men dare not explore. It is a truth he 
wishes he could somehow forget. He has lost his innocence and now knows the ways of the world, or at least of Lovecraft's unnatural world. Even as he tells the story, he attempts to forget what he has learned: "Let's have a drink before we get any deeper," he suggests as he begins to tell the story, and we cannot overlook Lovecraft's pun. As the narrator does get "deeper" into the tale, he has another drink (18) before telling about Pickman's paintings. Then, just three paragraphs later, he becomes almost mad with agitation as he describes the paintings and refills his glass again: "Give me that decanter, Eliot!" (19). When the tale is finished, the narrator sobers up before telling the final truth about the photograph. "Why did I drop him? Don't be impatient. Wait till I ring for coffee. We've had enough of that other stuff, but I for one need something" (24).

As the narrator tells his story and drinks from his decanter, he propels us deeper and deeper into the mad, horrible world of Pickman. His drinking is an attempt to make this world less real. However, when he reaches the moment of truth, he realizes that nothing will blur the reality of what he has seen. He orders coffee, a symbol of sobriety and reality, and once again recognizes what he has seen as the truth. From a narrative point of view, this also restores the narrator's reliability. If he were some drunken madman, his tale would hold no credibility. His utter seriousness and sobriety at this ending is reflected 
not only by his ordering coffee, but by his shorter sentences as he moves from long, descriptive passages filled with adjectives and adverbs to a stark, simple noun-verb prose. The truth, when it appears, is told simply: "It was the model he was using - and its background was merely the wall of the cellar studio in minute detail. But by God, Eliot, it was a photograph from life" (25). Applying the cultural code to the tale reveals Lovecraft's concern with an age-old problem-- what society will accept as artistic. Lovecraft chose to write horror for the sheer love of it. "...it has really ceased to be of any interest to me whether anybody reads my junk or not....I want the fun of writing it...." (SL III 235). Yet, as a writer of the macabre, Lovecraft was concerned with the genre's acceptance as serious literature, as he states in his critical essay, "Supernatural Horror in Literature":

The oldest and strongest emotion of mankind is fear and the strongest fear is fear of the unknown. These facts few psychologists will dispute, and their admitted truth must establish for all time the genuineness and dignity of the weirdly horrible tale as a literary form. (D 347 ).

Society, as a whole, has always held a schizophrenic view of horror. People are simultaneously revolted and attracted by fear, as is evidenced by the crowds that 
inevitably surround a fatal automobile accident. "Pickman's Model" shows this duality of fear in action.

The Art Club shuns Pickman because of the subject of his creations, even though the narrator states that "Boston never had a greater painter than Richard Upton Pickman." While Lovecraft recognizes that horror has traditionally been shunned by polite society, he also recognizes mankind's fascination with the macabre.

The narrator is originally fascinated by and attracted to Pickman's work, so much so that it induces him to begin work on a monograph upon the subject of weird art. He alone sees Pickman's genius, "...it takes profound art and a profound insight into Nature to turn out stuff like Pickman's" (13). Although he remains terrified of subways and basements, he retains his fascination with Pickman even as he relates his narrative to Eliot. The narration itself displays his interest. Although he initially tells Eliot that his fear of the subway is his own business, he needs little coaxing to tell the story of Pickman's model, and actually seems to relish in the telling of the tale. Looking at "Pickman's Model" through the connotative code shows Lovecraft's conception of fear and the horrible. Lovecraft's monsters, unlike the ghosts and vampires that inhabit the Gothic tale of terror, are realistic, grotesque, and quite disgusting. In fact, Lovecraft was one of the first writers of horror to depict his monsters in such realistic terms, and, in so doing, he established 
many of the conventions for those who followed him.

Current writers of best-selling status such as stephen King (Danse Macabre 72, 102) and Robert Bloch ("Afterword", 394) have written of their indebtedness to him.

Lovecraft's monsters, rather than being "undead," are very much alive; they are freaks of nature that describe a world where evolution has gone wrong and produced sentient, amphibious creatures of unmistakable evil. Pickman's drawings of the creatures are depicted as "nauseous sketches and half-finished monstrosities." One monster is described as "the fiendish subject" with "pointed ears, bloodshot eyes, flat nose and drooling lips... scaly claws... mould-caked body...half-hooved feet" (22). Other monsters are shown engaging in cannibalism and human sacrifice-- definitely not the type of story for the faint of heart. The monsters represent his belief that "the basis of true cosmic horror is violation of the order of nature" (SL III 174), yet this is a violation of nature as we know it on earth, and, according to Darwin's theory of evolution, these monsters are scientifically quite possible. These beings are the product of evolution-- an unnatural, reverse evolution, perhaps, but evolution nonetheless. This scientific explanation of the possibility of the violation of nature makes Lovecraft's vision of horror realistic and frightening.

Lovecraft's realism goes beyond a mere desire to shock, disgust, or even frighten, however. Since his 
monsters represent truth-- the frightening possibility that evolution could produce such monstrosities-- it is only fitting that they be depicted in realistic terms. To the narrator, these beings are "unnatural," yet they are products of nature, not supernatural creatures. They, like the spider, the python and the rodent, have been formed through evolution, and only someone with Pickman's "profound insight into Nature" (13) can paint them. They are based upon the assumption that more primitive life forms may have evolved into thinking beings. They force us to wonder what life forms might be like elsewhere in the universe, where amphibians might be the dominant animal and fungi the dominant plant.

Lovecraft's scientific horror creates evil that is not only realistic, but can be explained in Darwinian terms. If one is to accept the truths that science offers, then one must also accept the possibility of such monstrosities lurking somewhere in the universe. Lovecraft, in fact, explains his method and philosophy of realistic horror through Pickman, "a thorough, painstaking and almost scientific realist" (21), an idea which we will explore in the textual code.

According to Roland Barthes, works of literature often contain a textual code which speaks about artistic process in writing and communication. This code is most obvious in works that speak about the process of writing or creativity (as in George Bernard Shaw's preface to Man and Superman, 
Wordsworth's "Scorn Not the Sonnet", or Stephen King's Misery, for example), yet exists in one form or another in virtually every text, for the mystery and art of the creative process has proven to be a universal theme in literature.

The character of Richard Upton Pickman symbolizes the creative artist and represents Lovecraft's philosophy of art. Although Pickman works with the visual arts, his ideas of art can be transposed onto literature, particularly the literature of the macabre. Pickman is a "realist", as is Lovecraft himself:

Any magazine-cover hack can splash paint around wildly and call it a nightmare or a witches' Sabbath or a portrait of the devil, but only a great painter can make such a thing really scare or ring true. That's because only a real artist knows the actual anatomy of the terrible or the psychology of fear - the exact sort of lines and proportions that connect up with latent instincts or heredity memories of fright.... ...the really weird artist has a kind of vision which makes models, or summons up what amounts to actual scenes from the spectral world he lives in (13).

Lovecraft believed in this philosophy and practiced it, as he states in "The Supernatural Horror in 
Literature": "Serious weird stories are ... made realistically intense by close consistency and perfect fidelity to Nature except in the one supernatural direction which the author allows himself..." (D 399) His details of the natural world are authentic, as when he equates Pickman with other artists: Paul Gustave Dore (1832-1883), an illustrator of Paradise Lost and Dante's Inferno; John Henry Fuseli (1741-1825), a Swiss artist famous for a painting called "The Nightmare", among other devilish works; and Anthony Angorola, an eccentric painter who illustrated Ben Hecht's The Kingdom of Evil in 1923 (Lovecraft also mentioned Angorola in an earlier story, "The Call of (thulhu"). He increases the realism of Pickman's horrible world by placing it within the historical context of the Salem witch trials and the time of Cotton Mather, and by using actual geographic locations in Boston such as the North End and Gallows Hill. In fact, the slum section where Pickman's studio was placed actually existed and was based upon a first hand trip to the section by Lovecraft (SL II 170).

Pickman, the artist, is a mirror of Lovecraft the writer. Both are "scientific realists," who depict evil in a life-like manner. And both used actual settings from the modern, everyday world to bring "the horror right into our own daily life!" (20).

In addition to speaking about artistic technique in the weird tale, Lovecraft also addresses the idea of the 
horror tale as literature. In this respect, the textual code and the cultural code work hand in hand. Pickman is not accepted as a "true" artist because of the subject matter he has chosen to work with. Yet, the narrator insists, Pickman has discovered artistic truth and has been able to convey this truth to others. The artist, in this case, has conveyed truth more accurately than the scientist: "Reid, you know, had just taken up comparative pathology, and was full of pompous 'inside stuff' about the biological or evolutionary significance of this or that mental symptom" (14). The scientist is "repelled" by Pickman, because Pickman is an insider to a truth that Reid cannot-- or will not-- comprehend.

In "Pickman's Model," horror is a window to truth. Fear is a true part of the human psyche and worthy of exploration in literature, yet, because of the nature of this subject, the tale of the macabre is certain to be shunned by polite society-- the academicians and the critics who determine what subjects are worthy of artistic expression.

Lovecraft, in his search for his own brand of artistic truth, concerned himself with the psychology of fear-- with those things which created universal fear in mankind. To Lovecraft, horror was the "violation of the order of nature." (SL III 174) Stephen King, a contemporary master of horror, agrees : 
larger, more awesome. Lovecraft grasped this, and it is what makes his stories of stupendous, Cyclopean evil so effective.... After all, what is the paltry inside evil of the A-bomb when compared to Nyarlathotep, the Crawling Chaos, or Yog-Sothoth, the Goat with a Thousand Young? ( 72$)$.

According to Barthes, meaning is produced through diametric opposition of symbols as found in the symbolic code. "Pickman's Model" uses two major symbolic codes: the modern/ancient and natural/unnatural. These codes are, in essence, linked, and their opposition produces the horror of the tale.

Lovecraft's first opposition, the modern and the ancient, calls attention to the age of the universe and to modern man's tiny place in endless eternity. "And before Goya you have to go back to the mediaeval chaps who did gargoyles and chimeras on Notre Dame and Mont Saint-Michel. They believed all sorts of things" (14). It is no accident that Pickman's studio is located in the most ancient part of Boston, a part of the city that is "overflowing with wonder and terror and escapes from the commonplace" (16). Horror, itself, is ancient in Lovecraft's work. According to Lovecraft's mythos, monsters existed before the earth itself, and inhabited the earth before mankind had evolved from the apes. Remnants of these evils still inhabit the 
earth, in ancient, underground caverns beyond the realm of man.

As Pickman says, the abode of these creatures "isn't so very far from the elevated as distance goes, but it's centuries away as the soul goes" (17).

The monsters are depicted as a primitive, ancient force that has been part of the human psyche since our prehistoric ancestors dwelled in caves. Lovecraft's evil predates Christian devils and demons, and is an ancient part of the very cosmos. These horrors are not the "tame ghosts of a salt marsh and a shallow cove" that we are accustomed to, but are the "the ghosts of beings highly organiwed enough to have looked on hell and known the meaning of what they saw" (15).

Lovecraft also uses the opposition between the natural and the unnatural to portray his horrors. As we have seen by looking at the story through the connotative code, the beings are depicted as unnatural, subhuman monsters that, in their own way, are a by-product of the natural process of evolution. This "reverse evolution" that Reid refers to (17) might be an unnatural process; however, it is scientifically plausible and can be accounted for according to the laws of nature. This, as we have seen, makes the horror more real-- and more frightening.

The codes of modern/ancient coupled with natural/unnatural, in effect, create a new type of horror, a horror that broke with the gothic conventions of ghosts, werewolves and vampires. Lovecraft's horror is not the 
product of the earth, but was created by science, nature and the cosmos. This horror is, as King says, "larger, more awesome" than the traditional thing that goes bump in the night. Lovecraft was to develop this new type of horror more fully in his Mythos stories, which not only place terror in a cosmic context, but actually create a new mythology of fear that gives horror a scientific basis for existence. 


\section{3. "The Call of Cthulhu":}

Flagship of the Mythos

H.P. Lovecraft once lamented "There are my 'Poe' pieces \& my 'Dunsany' pieces-- but alas-- where are my Lovecraft pieces?" (SL II 315). In retrospect, it is much easier for the objective critic to discover the "Lovecraft pieces" than it was for Lovecraft himself. These "typical" Lovecraft stories, although they differ from one another in many ways, all demonstrate a distinct style that is unmistakably Lovecraft. Although this definitive style has been mimicked (usually badly) by many of his disciples, it remains uniquely his own.

As one of the "flagship" stories of what has come to be known as the "Cthulhu Mythos", or, more accurately, the mythos cycle, "The Call of Cthulhu" can be considered a typical Lovecraft tale. A detailed analysis of this tale will, I believe, shed some light upon Lovecraft's style, narrative technique, and major themes. In this manner we can determine what makes the "Lovecraft pieces" unique and different from other stories in the "weird tale" genre.

Like virtually all of Lovecraft's best tales, the basic plot of "The Call of Cthulhu" is constructed like a mystery story and uses a number of literary devices to inspire and sustain suspense. Like most mystery stories, the tale does not begin at the beginning, but in medias 
res, as the reader is, in effect, invited to read the manuscript of the late Francis Wayland Thurston of Boston. Background information is supplied by a series of analepses beginning with "My knowledge of the thing began in the winter of 1926-27 with the death of my grand-uncle..." (DH 126). The main premise of the story recounts the investigations of Thurston and how he acquired and collated the knowledge that opened up "such terrifying vistas of reality."

From the very opening, Lovecraft's major objective is to inspire and sustain suspense as he leads his reader through the tale. Even the colophon "Found Among the Papers of the Late Francis Wayland Thurston of Boston" is calculated to arouse suspense. A closer look at these techniques is essential to an understanding of Lovecraft's technique.

The story opens with a generalization that is not only puzzling, but articulates one of the major themes of the story, namely mankind's eternal search for truth and the destructive powers of truth once it is found:

The most merciful thing in the world, I think, is the inability of the human mind to correlate all of its contents. We live on a placid island of ignorance in the midst of black seas of infinity, and it was not meant that we should voyage far. The sciences, each straining in its own direction have hitherto harmed us little; but some day the 
piecing together of dissociated knowledge will open up such terrifying vistas of reality, and of our frightful position therein, that we shall either go mad from the revelation or flee from the deadly light into the peace and safety of a new dark age. (DH 125)

The idea that the narrator has, indeed, managed to piece together fragments of information that have resulted in a terrible knowledge continues: "... there came the single glimpse of forbidden aeons which chills me when I think of it and maddens me when I dream of it." The obvious enigma follows: what could be so bad?, and the reader is lured into the story.

Lovecraft's narrator vows never to tell his secret or to provide the clues for others to do so because the knowledge is "forbidden." Yet with typical Lovecraft irony, the narrator proceeds to do exactly what he vowed not to. The journey, however, is not simple but requires the reader to travel along until the end, retracing Thurston's steps and repiecing the information together with him. To Lovecraft it was not so much the horror itself as the learning about it that was the most interesting and provided the most suspense. Furthermore, an analysis of the hermeneutic code leads immediately to an exploration of the narrative voice and the textual and symbolic codes, since in this story these codes are 
intimately intertwined to create both suspense and meaning. The narrative voice in "The Call of Cthulhu" is specifically designed to highlight the symbolic code's opposition between the search for knowledge and the safety of ignorance, and, as it transports the reader on this journey the textual code becomes the major component of this search. Since the story is, in essence, a manuscript found among Thurston's papers, the narrative voice can be thought of as a textual one, which Lovecraft develops through the clever use of a "Chinese box" technique. Thurston's written account contains a number of other accounts: the manuscripts and clippings of his uncle; the story of Inspector Legrasse as told to his uncle; and the newspaper clippings and manuscript of Johansen.

This textual voice is depicted as detached and objective as the credentials of all of its individual voices are carefully documented. Thurston's uncle and the late professor Webb are both respected academics, and Legrasse is depicted as an impartial observer, a police inspector accustomed to solving mysteries. Reliable newspaper accounts add to the authority of the textual voice and verify the record.

Thurston himself is shown as reliable, not only in his attention to specific details but also in his healthy skepticism, which slowly gives way to belief as he learns the truth. He initially dismisses Wilcox as an eccentric artist until his account is verified by newspaper 
clippings. And, in a clever misdirection, he hints that the cthulhu cult may be the work of sadistic madmen in Legrasse's tale: "Only two of the prisoners were found sane enough to be hanged, and the rest were committed to various institutions" (140).

As a result of the textual point of view, the reader becomes the protagonist of the story as he/she collates the various pieces of information in Thurston's papers, information that Thurston also collated from his various sources. The story, like a puzzle, requires the reader to "piece together dissociated knowledge" that will "open up such terrifying vistas of reality..." Although the narrator hopes to keep his forbidden knowledge away from mankind, he fails as the reader also solves the puzzle and gains the knowledge. This knowledge, when pieced together with other stories of Lovecraft's Cthulhu cycle, does, in fact, give a complete if fictional view of the universe.

By making the reader a character within his story, Lovecraft brings terror to a new level. Even as professor Angell died from knowing too much, so did Thurston. If one takes this idea one step further, the reader himself will be the next victim, since the reader is also privilege to this forbidden knowledge!

Lovecraft has sometimes been criticized for the lack of characterization in his works. Indeed, as Maurice Levy has observed, the majority of Lovecraft's characters are really Lovecraft himself. As S.T. Joshi has said: 
Characterization... was decidedly a secondary matter to Lovecraft; and his only care was to make his character sufficiently realistic as not to be noticeably unconvincing. And the obvious mine for the traits of his characters was himself.... ("Autobiography" 156)

Yet Lovecraft's lack of characterization, in many ways, is a product of the stories themselves and the themes he was attempting to create.

In "The Call of Cthulhu," as I have already noted, the reader becomes the major protagonist as he/she pieces together the bits of information necessary to solve the puzzle. Interestingly enough, the individual viewpoint characters within the narrative are already dead, (with the possible exception of Legrasse, who may have been killed after Thurston's demise, for all we know) killed by their own quest for and attainment of forbidden knowledge. The reader, then, is the only "character" left who knows the story of Cthulhu. All of the other characters appear for the specific purpose of imparting knowledge to the reader. Since they are not terribly important as individuals, it is not necessary for Lovecraft to depict them in great detail. Examining "The Call of Cthulhu" from the perspective of symbolic code brings us to one of Lovecraft's major themes: the insignificance of man in the universe: 
...Our human race is only a rival incident in the history of creation. It is of no more importance in the annals of eternity and infinity than is the child's snow-man in the annals of terrestrial tribes and nations." (SL I 24)

In all of his stories, mankind is shown as a tiny, inferior species at the total mercy of the cosmos and of other sentient and god-like creatures living within the universe. If mankind as a whole is insignificant, then how much more insignificant is the individual man? The individual character, to Lovecraft, was a vehicle for his plot and theme rather than a person to be studied and psychoanalyzed. It mattered little which character was involved-- the important fact was the nature of the cosmos, and the horror of the insignificance it attributed to man.

"The Call of Cthulhu" is a classic example of Lovecraft's theme of man's insignificance in the universe. The Cthulhu legend, which is told to Legrasse as a myth or folk legend, tells of beings from the stars who lived on the earth before the age of man. These beings still lived in some sort of suspended animation, waiting to be awakened when "the stars were right." In his cthulhu stories, (especially in his short novel At the Mountains of Yadness) Lovecraft depicts these creatures as indifferent rather than evil. They are the product of evolution and 
nature rather than the supernatural. As such, they regard mankind much as man might regard the fly. In a scenario such as this, it is not appropriate to dwell on character development, since the individual character is purposefully shown as unimportant in the cosmic scheme of things. As Lovecraft himself wrote:

Individuals are all momentary trifles bound from a common nothingness toward another common nothingness. Only the framework itself-- or such individuals as symbolize principles for defiance of principles) of the cosmic framework-can gain a deep grip on my imagination and set it to work creating. In other words, the only "heroes" I can write about are phenomenon. (SL V 19)

In this as in other stories, Lovecraft explores the theme of truth and knowledge, and the destructive potential of "knowing too much." John Gatto has theorized that Lovecraft learned that his father died of brain problems brought on by syphilis, and this knowledge inspired the repetition of this theme in his works. Yet despite Kenneth W. Faig, Jr's exhaustive study, The Parents of Howard Philips Lovecraft, no definitive evidence has arisen to either prove or disprove this conjecture. Lovecraft did know of his father's being committed to Butler Hospital for mental illness, as he wrote in several letters, and this 
taint on his past alone may have influenced him, particularly in works such as The Case of Charles Dexter Ward and "The Shadow over Innsmouth" where the protagonist is searching for his genealogical roots and discovers terrible secrets about his ancestors. Regardless of the origin of this theme, it does play a major role in the Lovecraft canon.

Interestingly enough, in "The Call of Cthulhu" as in "Pickman's Model," the artist, not the scientist, is depicted as the key to truth. "It was from the artists and poets that the pertinent answers came" (DH 131), while "the sciences, each straining in its own direction, have hitherto harmed us little..." To Lovecraft, knowledge and enlightenment lie in the artistic truth of the imagination. Unlike the methodical logic of the scientist, this knowledge "like all dread glimpses of truth" results from "an accidental piecing together of separate things," and this requires artistic imagination.

To Lovecraft, the insignificance of man in the cosmos was, perhaps, the greatest truth, a truth he had learned from the piecing together of separate things. Yet this truth was unpleasant and caused Lovecraft much grief:

I have been forced to confess that mankind as a whole has no goal or purpose whatsoever, but is a mere superfluous speck in the unfathomable vortices of infinity and eternity. Accordingly, I have hardly been able to experience anything 
which one could call real happiness; or to take as vital an interest in human affairs as one can who still retains the hallucination of a "great purpose" in the general plan of terrestrial life. (SL I 86)

The discovery of truth in the Lovecraft canon is always painful, unpleasant, and destructive. Thurston and his fellow narrators are destroyed by learning the truth, as are Charles Dexter Ward, Richard Upton Pickman, and dozens of others in Lovecraft's fiction. Lovecraft himself contemplated suicide on more than one occasion (De Camp, 257 ) and wrote "I shall probably die of my own hand some day...." (SL I 132).

Lovecraft's theory that imagination was the key to truth, even if that truth might be painful was, perhaps, a recognition on his part of the difficult life that an imaginative person leads in a society based on realism. This, of course, was particularly true in his writing, which was not commercially salable at the time:

Romanticism calls on emotion, realism on pure reason; both ignore imagination, which groups isolated impressions into gorgeous patterns and finds strange relations and associations among the objects of visible and invisible Nature. Phantasy exists to fulfill the demands of the imagination; but since imagination is so much 
widely diffused than are emotion and analytical reason, it follows that such a literary type must be relatively rare, and decidedly restricted in its appeal. (IDOD 11)

The power of imagination and its capacity to discover truth is symbolized in dreams, not only in the Dunsanian dream stories ("The Dream-Quest of Unknown Kadath", "The Silver Key" and "Through the Gates of the Silver Key"), but also in "The Call of Cthulhu" where the dreams of the artists and the poets depict an unpleasant and forbidden truth that is unavailable to the more logical scientists. Yet the articulation of this truth, through the "call" of Cthulhu, is powerful enough to bring the ancient entity back to life. Although the language of this call is unintelligible to most men, as is fantasy itself, the "textualization" of the message is enough to turn dreams into reality, as cthulhu awakes from its sleep. This idea parallels Lovecraft's attempt to make fantasy realistic by giving it a scientific premise rather than a supernatural one.

"The Call of Cthulhu" has become accepted as a classic tale of terror. Like all of Lovecraft's best fiction, this story goes beyond the realm of the traditional horror or science fiction story by introducing complex themes involving truth, imagination, and man's place in the universe. Some of what have been regarded as Lovecraft's 
technical flaws, such as a lack of complex characterization, are, in fact, products of the very themes he explores, and are a necessary part of the explication of these themes. Although his "purple prose" and 18th century prose style has, at times, infuriated readers and critics alike, Lovecraft was, indeed, a visionary who created an entirely new type of story, a new literary genre that took horror out of the haunted house and into the real world of the 20th century. By giving horror a scientific basis for reality, Lovecraft conceived the concept of cosmic horror that has redefined terror in the modern world, a definition that we will examine in greater detail in chapter 7 . But in order to complete our textual analysis, we will now turn our attention to "The Rats in the Walls", where we will take a structuralist look at the narrative devices that Lovecraft employs in his fiction. 
4. Narrative Devices and Meaning:

"The Rats in the Walls"

"The Rats in the Walls" has one of the most peculiar titles in literature, even in the horror genre. This title, of course, is a conscious device by Lovecraft to attract the readers of Weird Tales, which was his primary audience. A detailed study of the narrative devices of this story will demonstrate how Lovecraft created and maintained suspense for his readers, who demanded terror and surprise.

The first two paragraphs of the story form almost a short abstract of all that is to follow, as they introduce the major puzzles and plot resolutions without giving any detailed explanations. The first line of the story dates when the narrative will actually begin-- July 16,1923 . But the mystery begins much earlier, during the reign of James I, the narrator tells us, when "a tragedy of intensely hideous, though largely unexplained, nature had struck down the master, five of his children, and several servants..." (DH 26). The remainder of the first paragraph offers several additional teasers, as the reader learns 
that the narrator is an ancestor of "the only survivor of the abhorred line." This ancestor, we find, was not only a murderer, but was apparently "shaken by some horror greater than that of conscience or the law."

While this ancient riddle might be fascinating as history, Lovecraft uses the next paragraph to transport it to the narrative present as it effects the protagonist of the story directly. The narrator first explains the dread and hatred that the local natives have for his new home that he had specially built above the ruined foundation that had once belonged to his ancestor. This might easily be attributed to local superstition were it not for the last sentence of the second paragraph: "And this week workmen have blown up Exham Priory, and are busy obliterating the traces of its foundations."

This "abstract," which begins with workmen finishing their labors of construction and ends with them completing their labors of destruction, forms a tight and mysterious cycle that contains the entire story of Delapore and his ancestor. The remainder of the tale, in effect, answers the questions that these initial paragraphs propose.

By using a first person narrative voice, however, Lovecraft, erases the major question that horror fiction poses, namely the fate of the narrator. As we have seen, Lovecraft solved this problem in "The Call of Cthulhu" by having the narrator speak from the grave through his diary. In "The Rats in the walls," the narrator obviously does 
live to tell his tale. Lovecraft circumvents this potential dilution of suspense by magnifying the horror that the narrator has experienced. Delapore "let no expense deter" him in the restoration of his home, and took obvious pride in his accomplishment. What horror, then, could have caused him to destroy the place and have all traces of its existence erased? As the third paragraph suggests, the horror represents the truth that the narrator learns about himself and his ancestry.

Lovecraft uses a number of prolepses, or foreshadowing devices, to plant clues about the solution of the story's enigmas. The knowledge that Delapore's ancestor was a murderer offers the possibility that the narrator himself may commit murder, making his tale a confession type story similar to Poe's "The Black Cat" or "The Tell-Tale Heart." This, of course, winds up being the case, with the narrator, in effect, confessing to a crime much worse than mere murder, as we learn that he, too, suffers from a type of reverse evolution that forces him to regress to a rat-like cannibal at the story's climax.

The rumors about his ancestors and the myths and legends about both them and the rats are additional foreshadowing devices, which the narrator initially shrugs of $f$ as mere superstition. Then the rats actually appear, making the legends more concrete.

The narrator's cat becomes a foreshadowing device of sorts, as it first becomes aware of the rats in the walls. 
The cat, in a clever reversal, becomes almost an objective narrator in the story since it can sense evil that is beyond the realm of human understanding. Throughout the story, the cat remains the symbol of good while the rats symbolize evil. And, at the story's conclusion when

Delapore himself becomes a cannibalistic rat-man, the cat, still symbolizing good, turns upon its own master. The cat, then, gives credibility to Delapore's supernatural explanation, even when Delapore himself is exposed as an insane, no longer reliable narrator.

While the idea of the cat detecting evil could easily become a stereotype, Lovecraft manages to avoid the cliche through clever narrative devices. First, he candidly exposes the stereotype: "I realize how trite this sounds-like the inevitable dog in the ghost story, which always growls before his master sees the sheeted figure..." (33). This statement assures the reader that Lovecraft is fully aware of the weird tale tradition and is using the device out of purpose rather than ignorance. Second, by turning the cat against his master in the end, Lovecraft gives the animal credibility, making it a real character rather than a cardboard device to hunt ghosts.

Lovecraft makes novel use of his treatment of time in "The Rats in the Walls" in order to focus attention on the climactic scene of the short story, where Delapore becomes a rat-like creature himself and takes part in a cannibalistic feast of sorts. Although the speed of 
narrative movement may seem odd, examining Lovecraft's use of time through structuralist theory shows that the speed of narrative movement reflects the theme and content of the story.

Gerard Genette speaks of four speeds of narrative novement: the ellipses, where time is infinitely rapid; the summary, where time is relatively rapid; the scene, where time is slow; and the pause, where time stands still (Narrative 95). The ellipsis may be a traditional transition, such as "three days later...", or it may be a more subtle transition that jumps across a vast period of time, as when an author omits a period of time between chapters without directly telling the reader. The summary also moves the narrative quickly through time, but contains more description than the ellipsis. The ellipsis and the summary connect scenes. The scene, a more detailed minute-to-minute account of the action, attempts to create "real" time. Finally, the pause slows down time by describing people, places or things without actually contributing to the forward motion of the plot. Pauses can supply necessary background information and complement scenes by slowing down the action and delaying the resolution in order to create suspense. Important information may be conveyed during pauses while the reader waits to see what will happen next.

Lovecraft's use of time is interesting and, compared to contemporary horror stories, most unusual. The story 
begins with an extended summary of past events, breaking into the present just long enough to mention the workmen who are completing the demolition of Delapore's home. The summary of past events immediately resumes, and is interrupted only by a series of ellipses that provide the transitions from one summary to the next. These ellipses are traditional transitions, such as "On July 22 occurred the first incident..." (33). Where most science fiction and horror stories are organized into scenes which are separated by summaries and ellipses, "The Rats in the Walls" consists of initial summaries instead of scenes. These summaries depict habitual, continuous action rather than any specific event: "Such was the lore that assailed me as I pushed to completion... the work of restoring my ancestral home.... On the other hand, I was constantly praised by Capt. Norrys...." (31).

The first actual scene does not occur until the end of page 33, after nearly eight pages of summary-type narrative. And even this scene is almost a combination of summary and scene with no direct dialogue, but merely indirect speech between Delapore and his servant, and then Capt. Norrys.

As the story continues, however, summaries and pauses begin to separate scenes $(38-43)$ as Delapore and others travel below ground to explore the ancient ruins. Again, even the scenes are almost summaries in their structure, with no direct dialogue, except for the man who "croaked 
the hackneyed 'My God!'" on page 41. Finally, on page 44-45, Lovecraft provides a real scene as Delapore "discovers" his secret and regresses into the reversed evolutionary form of his ancestor. In this scene, we hear the first actual dialogue of the story, as Delapore begins his ranting, which soon becomes unintelligible. It is interesting to note that Delapore goes on to say that these ravings are "what they say I said," yet the accuracy of the transcription coupled with the fact that this is the first actual dialogue of the story prove otherwise-- that he, subconsciously at least, remembers everything.

The overall structure of "The Rats in the Walls" works to telescope time: after beginning with vast summaries detailing many years, the story slowly closes in upon itself, condensing time into smaller and smaller units which climax with a scene set in realistic time. This telescopic focus of time parallels the way we look at the Delapore family, which begins with a history of the family as a whole and then focuses upon a single terrible event in the narrator's life. While the time frame narrows and becomes more focused, the suspense heightens as the narrative closes in upon the narrator, trapping him within its fictional walls.

The denouement of the story returns to the fictional present and finds the narrator literally trapped within prison walls, where scurrying rats still torment his sleep. This ending, which finds Delapore on the verge of returning 
to his ranting, concludes with a suspension of narrative time in the form of a scene, a continuation of the telescoping of time that has occurred throughout the narrative. Ending the story with such a scene forces the reader to think about the future and wonder if the narrator will eventually join the scurrying rats and take his place with his "abhorred line." This open-ended question continues the horror past the story's ending, leaving perhaps the greatest horror to occur after the story has been told.

In terms of the action code of the story, "The Rats in the Walls," like "Pickman's Model," portrays a human seeking truth about monsters by descending into the darkness. Both Pickman and Delapore learn that they are, in fact, monsters. In "The Rats in the Walls", truth is symbolized by darkness, since the truth about Delapore's ancestors has been symbolically buried and kept in the shadows.

The bare statistics of my ancestry I had always known, together with the fact that my first American forbear had come to the colonies under a strange cloud. Of details, however, I had been kept wholly ignorant through the policy of reticence always maintained by the Delapores. ( DH 27 ).

Like the narrator in "The Call of Cthulhu," Delapore begins 
"piecing together the tales" about his ancestors, only to discover that the family is plagued with a history of gruesome "myths, ballads, and crude superstitions," some of which involved epidemics of rats. Once the narrator has completed the restoration of the family house, a new plague of rats begins, and he begins a physical search for truth that leads him below ground and into ancient catacombs of Roman origin, and, then, to regions even deeper and more ancient. Delapore is plagued with dreams that depict the truth through the imagination, yet he dismisses them as mere dreams until he discovers the ultimate horror beneath his house-- that his ancestors have interbred with the rats to create a new and degenerate race. As the tale ends, Delapore reverts to the ways of his primitive ancestors as he is found "crouching in the blackness over the plump, half-eaten body of Capt. Norrys..."

As in "Pickman's Model," darkness reveals a terrible truth based upon the concept of reverse evolution. In this story, as in Pickman, the human race has degenerated rather than improved, and this reverse evolution can be traced in successive layers of darkness beneath the earth.

"The Rats in the Walls" also introduces the idea of the "bad place" to horror fiction. Exham Priory, we are told, has been evil since the dawn of time, when terrible Druid rituals were said to occur there. This idea of the "bad place" was expanded by Lovecraft to include a number of tales set in the "bad" places of Arkham and Dunwich, and 
has become a common theme in horror fiction. The fact that this idea is more popular than ever is demonstrated by the success of Stephen King's Castle Rock and 'Salem's Lot stories, Charles L. Grant's Oxrun Station novels, and Michael McDowell's "Blackwater" series, to name just a few examples from the masters of modern horror.

Technically, "The Rats in the Walls" shows Lovecraft in control of his material, using specific literary structures and devices in order to achieve a desired effect-- that of sustaining suspense throughout the narrative, and then surprising the reader with the ending. Lovecraft's skill with these narrative devices has helped to make many of them standard techniques in contemporary horror. 
PART TWO

LOVECRAFT'S VISION OF HORROR 
PART TWO

Lovecraft's Vision of Horror

In Part One, we have looked at Lovecraft's major themes through an overview of "The Shadow Out of Innsmouth," and then have examined three of Lovecraft's best-known stories in intricate detail. This structural analysis has, I hope, been a useful tool in delving into the shadows of Lovecraft's fiction and has demonstrated that the stories are complex and meaningful works that use fantasy as a means to truth. The nature of this unique vision of truth will be examined in more detail in Part Three.

Above all, Lovecraft considered himself a writer of what he called the "weird tale", and would write no other type of story, despite the lack of a reputable professional market for his brand of fiction. Throughout his life, he believed in the importance of horror fiction as a genre, and its "genuineness and dignity... as a literary form" (D 365). His essay "The Supernatural Horror in Literature" demonstrates both his commitment to the genre and his seriousness about it. As a result of his passion for his craft, he has had a major impact on fantasy, science fiction, and horror, and has influenced an entire generation of writers, including Ray Bradbury, Robert 
Bloch, and Stephen King, all of whom have acknowledged their literary debt to Lovecraft. As evidence of this debt, the World Fantasy Award, a carved bust of Lovecraft, has been named the "Howard Award" in his honor, and is given each year for those works which evidence excellence within the genres of fantasy and horror.

In Part Two I will examine H.P. Lovecraft's contribution to horror fiction through a study of six of his works, each of which will highlight a specific aspect of his unique vision of the weird tale as literature. As in Part One, I will begin with a story that will establish certain fundamental principles-- in this case, "Dagon," an early tale that exhibits many of the ideas and techniques that Lovecraft developed with more proficiency in his later and better-know stories. I will then look at cosmic horror, a subgenre that Lovecraft was the first to define, the horror tale as mythology, the power of language in producing terror, and the relationship between irony and horror. While I will continue to use structuralist theory as my underlying principle, the analyses will be less detailed and technical than those in Part One, since my focus will be to elucidate Lovecraft's ideas about horror and literature. 


\section{5. "Dagon":}

The Fundamentals of Terror

"Dagon" is an early Lovecraft story, originally written in 1917, and was "the second story... after a nine years" silence" (SL I 202). Yet even in 1923, Lovecraft felt that he had "hardly been able to equal it since" (203). While critics agree that the later stories showed much more polish and skill than this early effort, "Dagon" does demonstrate the principles that Lovecraft believed essential to the successful weird tale. Even in this early work, Lovecraft recognized the importance of building suspense and of creating an atmosphere of dread, principles which would always remain an integral part of his work.

As we have seen in Part One, the author of horror fiction must create and maintain suspense throughout the narrative if the story hopes to succeed. Lovecraft realized that his audience desired and expected this dramatic tension, and, as we have seen in "The Rats in the Walls", he consciously used a number of narrative devices to accomplish this effect.

The choice of point of view can be problematic in horror fiction, because a first person point of view 
reveals that the narrator will live to tell the tale, thus, eliminating some of the suspense. Lovecraft uses a number of devices to circumvent this problem, and even in a first person narrative, the protagonist's survival is never assured. In "Dagon" the first sentence initiates suspense by questioning the narrator's survival as it makes the story a potential suicide note of sorts: "I am writing this under appreciable mental strain, since by tonight I shall be no more" (D 14). Thus, while the protagonist may indeed survive to write the tale, he probably will not live long thereafter. The certainty of the "happy" ending is immediately eliminated.

of course the fact that the protagonist is contemplating suicide calls into question his reliability as a narrator. He admits that he has been under "mental strain" and is hopelessly addicted to morphine. While many of Lovecraft's later protagonists tell incredible tales, Lovecraft is careful to make them credible narrators. As we have seen in "The Call of Cthulhu," which closely resembles "Dagon" in plot structure, the narrator's accounts are verified by newspapers, professors, and other reliable sources. One of Dagon's major flaws lies in Lovecraft's failure to make this narrator reliable.

In the very first paragraph, the narrator attempts to legitimize himself: "Do not think from my slavery to worphine that I am a weakling or a degenerate" (14). But this self-testimonial is not, in itself, enough. 
Lovecraft's chance to make his narrator truly reliable comes later, with mention of the "celebrated ethnologist" and the "ancient Philistine legend of Dagon, the Fish-God" (19). He later perfected his technique of lending credibility to his narrator's unbelievable tales by better referencing them to known facts. In "Dagon" this technique is still in the embryonic stage. Had he developed this idea further it would have heightened the narrator's credibility-- and increased the tale's sense of terror and dread. For example, the ethnologist could have expressed amazement with the narrator's describing the fish-god without being familiar with the obscure mythology that spawned it. Lovecraft would use this type of device in later tales of his Cthulhu stories, to great advantage. Yet, despite story's failings Lovecraft has already shown a knack for building suspense right from the very first sentence, which predicts the protagonist's own death. In the first paragraph he alludes to the fact that he has suffered terrible mental torture and says that his pain is so great he must have "forgetfulness or death." The reader, of course, is left to wonder exactly what has caused his suffering and what terror he must forget. The answer to this enigma forms the basis for the story.

The tale has a circular structure that begins and ends with the narrator writing his story. In "Dagon," as in many of Lovecraft's works, the act of writing forms an important part of the plot and theme. In "The call of 
Cthulhu", "The Haunter in the Dark", and "Dagon," the narrator leaves behind a written record of the horror, either in diary or journal form, or as a type of dying confession, a "last word," if you will. In these stories, the writing almost transcends death, since it leaves behind a visible truth, a permanent record that can be examined analytically. "Dagon" provides an excellent example of this technique in action.

The narrator of "Dagon" is driven to write, to record his version of truth even though he is under mental strain and on the verge of death. In fact, he feels that he cannot even kill himself until he completes his written record "for the information or the contemptuous amusement of my fellow-men" (19). Although he feels that his last words contain an important truth, he realizes that they will probably not be taken seriously. This thought echoes Lovecraft's ideas about supernatural literature in general and his own writing in particular-- that it would never be taken seriously by the critics.

Even though neither Lovecraft nor the narrator of "Dagon" expect to influence anyone through narrative, they still must write, though they realize their efforts will probably be in vain. Through writing, man can leave behind something of himself, some tiny bit of existence-- even as youths must leave graffiti behind on subway walls, so must Lovecraft and his narrators write, whether or not their efforts will be appreciated. Writing mirrors life, and 
when the writing ends, the protagonist symbolically dies. Not only must the narrator write, but he recognizes his inability to do so, and struggles with this. From the very beginning, he realizes the impossibility of his task-describing the ultimate horror and making the uninitiated believe in its existence. "When you have read these hastily scrawled pages you may guess, though never fully realize, why it is that I must have forgetfulness or death" (14).

Lovecraft, through the persona of his narrator, experiences the dilema of all writers of terror: describing the horror fully enough to make the reader believe, while leaving enough to the imagination to make him afraid. "Drawing the line between concrete description and trans-dimensional suggestion is a very ticklish job," Lovecraft wrote to one of his friends (SL III 174). The narrator in "Dagon" also struggles with the inability of language to create terror: "Perhaps I should not hope to convey in mere words the unutterable hideous that can dwell in absolute silence...." (15). As Joshi has observed (Decline 112), Lovecraft understood that traditional Gothic metaphors cannot express his cosmic form of horror. The narrator of "Dagon", in a textual code that demonstrates this understanding, remarks that the bas-reliefs were "grotesque beyond the imagination of a poe or a Bulwer" (18). In fact, part of the mood of terror may come from this inability to capture the horror in words-- 
in "The Colour out of Space," as we will see, the premise of terror stems from the "unnamable" color. I will develop this idea in further detail in my analysis of "The Unnamable".

H.P. Lovecraft believed in the necessity of creating a mood or atmosphere of terror in order for the weird tale to be successful. "Atmosphere is the one essential in this field, because atmosphere is the only medium whereby anything as elusive and intangible as a mood can be even approximately recreated" (SL III 427). While Lovecraft certainly creates an atmosphere of terror and dread through narrative devices that produce and heighten suspense, his connotative use of language and images replaces the traditional character development of most authors. Thus, the object of horror or terror becomes, in many ways, the main character of the story, even though it is seldom seen and understood in its entirety.

In "Dagon," Lovecraft uses human senses to develop the connotative code of terror and repulsion. The sensation that the narrator receives through sight, sound, smell and touch all combine to create an overall mood of horror and fear. The major connotative codes of sight are vastness and blackness, which commence with the narrator's being set free upon the "heaving vastness of unbroken blue" (15). First he drifts in the vast ocean, and then wakes up to discover himself trapped in "a slimy expanse of hellish black mire which extended about me in monotonous 
undulations as far as I could see..." This island is then described as a "barren immensity", "black" and "inky." These connotations, taken together, reproduce an infinite black universe into which man has suddenly found himself. Indeed, as early twentieth century science began its exploration of space and the stars, the limits of the universe suddenly expanded to become a "barren immensity." The narrator's fear stems from his smallness amid the infinite blackness around him, an instinctive fear, perhaps, of man's insignificance in the universe, a theme that Lovecraft explores in virtually every story he has written. The universe, with its infinite size and blackness, 'defies man's understanding of it and exists as an independent force outside of his control.

The major connotative code of sound is silence-- the absence of sound. This silence not only reinforces the idea of the vastness of the universe, but symbolically reminds man of his own mortality. Silence, of course, represents death. The protagonist attempts to overcome death through narrative. The first person narrative speaks even after death, giving a certain textual immortality that may be the only way man can leave his mark on the universe. Ironically, even though the narrator does not expect his tale to be taken seriously, it remains his only defense against the ultimate silence of death.

In fact, when the narrator first encounters the monster, his only defense is to sing, to break the silence 
in an attempt to preserve his own life and sanity: "I believe I sang a great deal, and laughed oddly when $I$ was unable to sing" (18). His song, perhaps a form of art or poetry, evaporates into amusement, as does his story, which was "given scant attention." Since narrative symbolizes life, the protagonist later attempts to preserve his own life by continuing his narrative right until the end.

The Dagon fish-god cult is also given life through the ancient $\mathrm{Philistine} \mathrm{legends,} \mathrm{and} \mathrm{in} \mathrm{later} \mathrm{stories,} \mathrm{Lovecraft}$ continued to give his monsters life by creating his own elaborate mythologies around them, including the "dreaded Necronomican" and other mythical texts that offered credibility to the cthulhu cult. This "textual life" has assumed such power that there are those who have attempted to make the Necronomican real by placing counterfeit index cards in various libraries to authenticate it, and, as a result, there has been a historical confusion as to whether or not the work exists. To further complicate the matter, a paperback book of spells based upon Lovecraft's works and titled The Necronomican has recently been published.

The connotative codes of smell and touch also work to remind man of his immortality. These connotations, revolving around slime, ooze, and decay, depict the frailty of the living organism and its susceptibility to even nature's smallest members-- bacteria and micro-organisms. Lovecraft's evils are invariably depicted in terms of decay and putrification: either they are decaying themselves, or 
fungus-like, thrive on decay. In "Dagon," the smell and touch of rotting $f$ ish is "maddening," and the fish creature is imagined as "crawling and floundering on its slimy bed." The connotations of slime and ooze coupled with the references to $\mathrm{fish}-1$ ike creatures also refer to the Devonian period of approximately 400 million years ago when the earth was dominated by fishes. During this time, most of the world was water, mud, or swamp, and amphibians first crawled from this primeval ooze to populate the land. Lovecraft's terrible island is a recreation of this primitive landscape, and a look at what the world might have been like had fish evolved into the dominant life form. Yet Lovecraft not only asks the question of "what if fish evolved further," but postulates that they, in fact, have done so in certain areas of the deep obscured from human eyes. As we have seen in "Pickman's Model" and "The Rats in the Walls," this reverse or parallel form of evolution forms the basis for a number of Lovecraft stories. According to Burleson, these "unwholesome survivals" interact with other Lovecraftian ideas to create the theme of "illusory surface appearances" (Disturbing 157). This notion that "things are not what they appear" interacts with man's desire for forbidden or destructive knowledge to create terror. As we have already seen, the horror depends not so much upon the nature of truth, but upon its discovery. In "Dagon" the protagonist is not destroyed by the fish god, but by his knowledge of its 
existence and his desire to share that knowledge with others. He cannot survive because he cannot forget or ignore what he has seen.

The action code of "Dagon" mirrors evolution as the protagonist, like our piscine ancestors, crawls from water onto mud and then to higher ground. Dagon undergoes a similar evolution, signifying the emergence of a new and more powerful life form than man. And even as the protagonist returns to civilization, so will the Fish-God follow him and devour him, as its race is capable of devouring mankind as a whole.

While "Dagon" is an early story, it demonstrates many of the techniques and themes that Lovecraft was to later develop and improve upon. The notions of forbidden knowledge, mythology, parallel evolution, and the power of narrative are evident even in this early story. Perhaps Lovecraft recognized his future themes in "Dagon" and that is why it remained one of his personal favorite stories. 


\section{6. "The Shunned House": \\ The Irony of Horror}

"The Shunned House," written in 1924 , represents a transitional phase in Lovecraft's fiction, as his work evolved from the typical Poe-esque Gothic horror tales, to the Mythos stories, beginning with "The Call of Cthulhu" in 1926. In fact, a close reading of the text reveals both an acknowledgement of Poe's genius, and an acceptance of the fact that Poe's romantic type of Gothic horror was an inadequate vehicle for the expression of horror in the modern world of realism and science.

While "The Shunned House" is often dismissed as just another vampire story, the tale deals with and helps define the nature of horror by contrasting the "phantasy" stories of Poe, Dunsany, and others with the realistic cynicism of the scientist. This result-- an irony of horror-- set the stage for the Mythos stories that were to follow.

"The Shunned House" opens with the cryptic passage: "From even the greatest of horrors irony is seldom absent," then spends the first full page of the story explaining the irony. This seems most unusual coming from an author who 
wrote in 1926 that "Irony used to interest me when I was younger \& more impressed by the hollowness of the things it castigates, but nowadays the current hypocrisies do not seem important enough to me to warrant the expenditure of artistic effort against them" (SL II 62). Obviously, Lovecraft used irony in a much different manner than those who "castigate... current hypocrisies." In fact, to Lovecraft, horror may have been the only subject important enough to be worthy of artistic irony.

In expressing $h$ is concept of irony, Lovecraft develops the image of Edgar Allan Poe, the world's greatest writer of the macabre, dreaming of ghosts and make-believe dungeons as he passes a real-life horror during his walks on Benefit Street. Legend has it that Poe first saw Sarah Helen Whitman during his Benefit street walks in the summer of 1845 , just a few months before the Daily Transcript and Chronicle article of October, 1945, where a middle-aged school teacher was "transfigured in a horrible way." It is significant that the real house "... equals or outranks in horror the wildest phantasy of the genius who so often passed it unknowingly."

As Joshi has noted, Lovecraft does not demean Poe in any way, but is "merely hinting that any fictional work-even that of a genius-- cannot rival the horrors concealed on the underside of reality" (Decline 114). The irony does, however, establish an opposition between realism and fantasy, science and supernatural and the tale itself blurs 
the traditional boundaries between the two. After exploring the two poles, Lovecraft places horror on the side of realism and notes that Poe, the romantic, overlooked the real.

The idea of traditional horror serves as an undercurrent to "The Shunned House" as it pervades much of the tale and gives the first impression of a typical vampire story. This traditional view is expressed by the legends of the "common folk," who believe the house is inhabited by vampires or werewolves. The vampire theory, which expresses irony in being both "the most extravagant and at the same time most consistent tale", represents supernatural horror with no scientific basis. Ann White, the servant who championed the vampire explanation, needed no scientific research to develop her theory.

In contrast with the supernatural, we find the theory of bad air, some type of explainable disease caused by the propagation of fungoid growths within the basement of the shunned house. While this theory is easy enough to believe, it doesn't explain all of the strange happenings on Benefit street, such as the mystery of why victims would babble in French before they died.

It should be noted that the shunned house, even with its vampire possibilities, contains none of the traditional Gothic trappings, the Poe-esque details that one might expect in a tale of terror. Even the folklore is consistent on this point: "There were no widespread tales 
of rattling chains, cold currents of air, extinguished lights, or faces at the window. Extremists sometimes said the house was 'unlucky', but that is as far as even they went" (MM 237).

These two poles remain at odds throughout the tale, and, at times, Lovecraft leads us down the road of traditional supernaturalism, misdirecting us from his real objective, the science of the supernatural:

We were not, as I have said, in any sense childishly superstitious, but scientific study and reflection had taught us that the known universe of three dimensions embraces the merest fraction of the whole cosmos of substance and energy. (251)

The narrator decides to treat the subject with "profound seriousness," as he begins his investigations into both history and science:

To say that we actually believed in vampires or werewolves would be a carelessly inclusive statement. Rather must it be said that we were not prepared to deny the possibility of certain unfamiliar and unclassified modifications of vital force and attenuated matter.

Horror does not supplant reality, but exists within the realms of science and explores possibilities in areas that 
science does not know. The narrator argues that a malignant entity "... was surely not a physical or biochemical impossibility in the light of a newer science which includes the theories of relativity and intra-atomic energy." His fantasy is, ironically, based upon a realistic concept and in its attempt to show man's lack of knowledge, speaks of a realistic truth.

In discarding supernaturalism for science, the narrator uses modern technology to combat the monster. Instead of arming himself with wooden stakes and garlic, this protagonist uses a flame thrower and a newfangled scientific mechanism "procured from the laboratories of Brown University." And, unlike most of Lovecraft's narrator's, the protagonist of "The Shunned House" does succeed in ridding the world of the monster, though at the cost of his uncle's life. The "vampire" can be and is destroyed by scientific means rather than magic or supernaturalism. This concept removes "The Shunned House" from the traditional horror genre and places it within the realm of science fiction, a landmark idea that led to the creation of Lovecraft's masterpieces of the Mythos.

In recognizing the realism of horror Lovecraft discovered its irony-- that science and truth are more frightening than anything we can conjure from the supernatural. "There is, in my mind, a kind of hideous irony in the assumption of the human point of view at all..." (SL I 172), Lovecraft wrote, acknowledging his 
belief that the human race is but a tiny, insignificant part of a vast universe, and that other, nonhuman points of view may be more important in the cosmic scheme of things. According to Lovecraft, Einstein's theories could better evoke terror than could the fiction of Poe, and, though he hated realistic fiction in the traditional sense, his stories of fantasy did become increasingly realistic in their own way.

"The Shunned House" is a mediocre tale, as Lovecraft himself realized. Its lengthy description of genealogies and history is excessive, its plot devices are established too late, and the protagonist defeats the monster much too easily. Yet by giving a scientific basis to a traditional trapping of Gothic horror, Lovecraft created a completely new type of horror story incorporating both science fiction and horror. "The Shunned House," in its similarity to The Case of Charles Dexter Ward was, perhaps, an embryonic stage of that longer work. More importantly for Lovecraft studies, "The Shunned House" with its irony of horror defines the principle of realistic, scientific horror that was to become the trademark of the Mythos stories. It was this realistic horror that took the weird tale from the shadows of the gothic haunted house and into the modern world, establishing the new genre of cosmic horror. 


\section{7. "The Colour Out of Space": \\ Cosmic Horror Defined}

Since the beginning of time, mankind has been intrigued by the stars and captivated by their beauty. Over the course of the centuries, they have been worshipped, wished upon, and wondered about. Yet, even in their infinite beauty, the stars and the cosmos they represent have been a constant source for terror, as they have predicted disasters and symbolized the great unknown. It is no surprise, then, that writers of terror have turned to the cosmos as a source of inspiration. From the Wr of the Worlds of H.G. Wells, to the flying saucer films of the 1950's to more modern invasions such as Day of the Iriffids, The Andromeda Strain, King's The Tommyknockers and McCammon's Stinger, alien invasions of various sorts have bridged the gap between horror and science fiction, sometimes with great success.

H.P. Lovecraft, one of the fathers of the scientific horror tale, realized the potential terror embodied in the cosmos and became one of the world's greatest practitioners of "Cosmic Horror." Unlike most of the current crop of 
alien invasion writers who rely merely on destruction of the earth by bug-eyed monsters, Lovecraft understood that the terror of the cosmos is more than "skin deep," but touches man's innermost fears of the unknown.

H.P. Lovecraft considered "The Colour out of Space" one of his most successful stories, and the tale survives as a classic of both horror and science fiction. A detailed analysis of this story shows that it succeeds by transcending the boundaries of the typical alien invasion story as it touches the collective subconscious of the human race.

Chronologically, the story begins when a strange meteorite lands in a secluded area west of Arkham, and slowly transforms it into a "travesty of the Garden of Eden" (Cannon 85) where the animals, vegetation, and even human inhabitants in the form of the Gardner family become altered and then destroyed. The narrative, of course, commences after the fact, when a land surveyor appears to map the area prior to its flooding to create a reservoir for drinking water, and ends with the terrible suggestion that the entity may very well reappear in the water once the reservoir is completed.

"The Colour Out of space" has been called "H.P. Lovecraft's Book of Job" (Gatto 53), yet the true terror runs far deeper than this. The real horror of the story is embodied in the strange unnaturalness of the alien life form itself; this strangeness is symbolized by its color, 
which is different from any known color and "almost impossible to describe," (DH 59) Even when placed under a spectroscope, the color can not be categorized under our present system of knowledge.

Burleson has observed the deconstructive possibilities of this idea as concerns textuality:

To suggest, as the text does, that there may occur a color, a visible impression, not belonging to this system, is to suggest subversion of the system and, allegorically, subversion of systems generally. What is at work here is the undoing of categorical thinking, the unraveling of any system claiming final mastery, exhaustive cataloguing, total solution, immutable results, settled 'reading' of reality.

This subversion is interesting from a deconstructive point of view and does seem to indicate points of "slippage" in the text. Yet more importantly, this subversion of reality forms the essence of cosmic horror and, in effect, defines the genre.

"The basis of all true cosmic horror is violation of "order of nature" Lovecraft wrote, "and the profoundest violations are always the least concrete and describable." (SL III 174) While the creation of an alien of a "different" color might seem a small thing, certainly not as frightening as the aliens of Wells or King, aliens that 
can vaporize entire planets, this unknowable color, in fact, undermines everything that the human race knows-- or thinks it knows-- about the universe. Furthermore, it effectively nullifies man's quest for a universal theory that would explain the cosmos, and, in essence, leaves man with the realization that the universe ultimately cannot be explained. This view, contrary to human thinking and human nature, is frightening in and of itself, and opens up the possibility that anvthing is possible.

The aliens of H.G. Wells and others, regardless of their power, are subject to nature's laws. The invaders of of the Worlds can be destroyed by microscopic bacteria, despite their superior intelligence and power.

Lovecraft's alien substance (if it even has a substance) does not obey the laws of nature as we know them, but is a product of laws that work contrary to those in the known universe. Since the colour cannot be analyzed by modern spectroscopy, it must be composed of elements different from those of the Periodic Chart that we are familiar with. Every star, every galaxy, and every nebula in the known universe can be measured with a spectroscope and related to the Periodic chart of the elements; yet this alien is different from anything that can be know or imagined.

Since the beginning of civilization, the human species has strived to find order in a mysterious universe, and, for the most part, has been successful. Where mysteries 
still exist, scientists have remained confident that they relate to universal laws that have simply not been explained yet. The search for a "Unified Theory" continues and, will no doubt, be found, in time.

In "The Colour Out of Space," Lovecraft speculates that there may be no order to the universe after all, that all of mankind's theories may be useless. This concept is a negation of everything we know, of everything we have learned or can attempt to learn.

The color is a simple thing. Yet in this "violation of the order of nature," lies the true terror and that in fact, defines cosmic horror. Perhaps Lovecraft said it best:

The true function of phantasy is to give the imagination a ground for limitless expansion, \& to satisfy aesthetically the sincere \& burning curiosity \& sense of awe which a sensitive minority of mankind feel toward the alluring \& provocative abysses of unplumbed space \& unguessed entity which press in upon the known world from unknown infinities \& in unknown relationships of time, space, matter, force, dimensionality, \& consciousness." (SL III 196)

This inability of man to know and understand negates all of our beliefs, both scientific and philosophical. As we will see in the next chapter, Lovecraft used this premise as a 
device to replace traditional beliefs with a new myth system-- the mythology of fear. 
8. "The Dunwich Horror":

The Mythology of Fear

"The Dunwich Horror," written in 1928, is a Cthulhu mythos story where Yog-Sothoth has "begotten hellish hybrids among the females of various organic species throughout the universes of space-time" (SL V, 303). This story, which can be thought of as a cosmic version of the mating with the devil motif (The Omen and Rosemary's Baby), results in the birth of a monster that could open the cosmic gates to alien invaders from beyond space and time. Set in the rural farmlands of western Massachussetts, the story begins as a fairly straightforward tale of witchcraft and Satanism as Wilbur Whateley takes on the characteristics of an antichrist. Only later, as his twin brother is revealed, does the reader learn the cosmic significance of the union between Lavinia Whateley and the Great old One.

With its obvious references to mythology, legend and folklore, Lovecraft's tale of Dunwich can be used as a model to establish and define the mythology of the horror tale both as a genre and as a form of modern mythology. The story's epigraph, taken from Charles Lamb's "Witches 
and Night Fears," warns that "the archetypes are in us, and eternal.... terrors are of older standing. They date beyond the body." According to Lovecraft, fear and horror are part of the human experience; the tale of terror is an archetype "as old as human thought and speech themselves" (D 369). As Lovecraft reminds us in "Supernatural Horror in Literature" :

Because we remember pain and the menace of death more vividly than pleasure, and because our feelings toward the beneficient aspects of the unknown have from the first been captured and formalized by conventional religious rituals, it has fallen to the lot of the darker and more maleficent side of cosmic mystery to figure chiefly in our supernatural folklore. This tendency, too, is naturally enhanced by the fact that uncertainty and danger are always closely alljed; thus making any kind of unknown world a world of peril and possibilities. When to this sense of fear and evil the inevitable fascination of wonder and curiosity is superadded, there is born a composite body of keen emotion and imaginative provocation whose vitality must of necessity endure as long as the human race itself. Children will always be afraid of the dark, and men with minds sensitive to the hereditary impulse will always tremble at the 
thought of the hidden and fathomless worlds of strange life which may pulsate in the gulfs between the stars, or press hideously upon our own globe in unholy dimensions which only the dead and the moonstruck can glimpse.

with this foundation, no one need wonder at the existence of a literature of cosmic fear. (D 367 )

"The Dunwich Horror" takes Lovecraft's philosophy of horror as archetype and puts it into practice, effectively defining horror as myth and defending the weird tale as a valid component of both literature and society. In order to accomplish this task, Lovecraft establishes a binary opposition between the "beneficent aspects of the unknown", represented by traditional religious mythology, and the "darker and more maleficent side of cosmic mystery", which is, of course, the weird tale.

As Levi has suggested, "The Dunwich Horror'... is the unbearable story of a reverse gospel, an inverse history of salvation" (95). Yog-Sothoth, the Great old One, becomes a metaphor for God, Lavinia Whateley represents the Virgin Mary, and the spawn of this perverse coupling-- the Whateley twins-- becomes a perverse reversal of Christ. Even the Bible is parodied in the form of the dreaded Pecronomican which predicts the triumph of evil.

This hideous reversal is upsetting and disturbing on 
several levels. First, and most obvious, the story alludes to blasphemy and "forbidden" literature, an idea that I will develop as we examine the textual codes of the story. secondly, the story establishes the conflict between traditional mythology and the tale of terror. Lovecraft not only reverses the gospel, but, by placing the reversal in a cosmic context of space and time, positions it within a scientific context. This new mythology not only looks back to the archetype of past unknowns, but anticipates future horrors "which may pulsate in the gulfs between the stars."

While establishing a new, scientific mythology, Lovecraft remains true to the structure of the traditional folktale, even in his reversal. Wilbur and his hideous twin, when considered as one, become the archetypal "hero" of the myth, as Burleson has pointed out (Disturbing 124). Furthermore, the Whateley twins conform to Vladimir Propp's definition of the mythic hero (Morphology 120): they are created as the result of a miraculous birth, experience rapid growth, and embark upon a quest for knowledge or a magical agent.

As is typical in Lovecraft's fiction, there are no real human heroes. Using Propp's definition of the mythic hero, the trinity of Armitage, Rice and Morgan are not heroes at all, but represent obstacles for the whateley twins. Indeed, Lovecraft's belief in man's insignificance in the universe precludes the possibility of mythic human 
heroes and explains the frailty of the three professors. "The Dunwich Horror" represents a complete reversal of the archetypal "hero quest" myth in virtually every way. Lovecraft twists the typical mythic hero into a perverse and disgusting reversal, with the monster taking on the hero's role, and a trinity of three weaklings attempting to slay the dragon. Even the traditional happy ending of the myth is reversed; the slaying of the hero/monster creates an ironic reversal where good still triumphs over evil, at least for the moment. Yet, since good and evil are defined in human terms-- Yog-Sothoth no doubt has different ethics-- the tale, from the hero/monster's point of view does not have a happy ending. As with the story of Christ's crucifixion, however, we haven't heard the last of this, as the Necronomican prophecises "They shall soon rule where man rules now." (DH 170).

By reversing the traditional myth, "The Dunwich Horror" forms an archetype for the mythology of fear; if typical mythology represents wish-fulfillment with its "happy ending", then horror represents the opposite-"nightmare fulfillment," if you will. These two sides of myth, fantasy and horror are representations of Freud's ideas of dreams as symbolizing objects of desire or fear. These two aspects of dreams, when projected into literature, become the basis for fantasy and the weird tale, respectively.

In her book Fantasy and Mimesis, Kathryn Hume 
discusses fantasy as a form of escape. The traditional fantasy resembles a "daydream story" (The Wizard of $\mathrm{O}_{2}$, Three Musketeers and virtually any romance novel, for example) and invites the reader to escape from reality. These stories "encourage passive relaxation,... stir active thoughts of aggression, and ... feed one's sense of superiority." (73)

The tale of terror, on the other hand, is a form of affective literature, which provides "forms of escape that in one way or another raise and maintain tension, usually causing a sense of inferiority" (74) which, according to Hume, 'provides pleasure in a different way:

People submit to feeling upset, perhaps because feeling strongly is one proof that one is alive... The reader not only gets the benefits of having darker emotions whipped to a froth, but can also enjoy the relief that comes when the experience stops. (79)

Lovecraft's stories in general, and "The Dunwich Horror" in particular, take the feeling of inferiority to its limit by depicting mankind as nothing more than an insect in a hostile universe. To Lovecraft, nothing is sacred; his reversal of the escapist fantasy and even religious beliefs compounds this sense of inferiority, as does his perverse inversion of the mythic hero. Thus, the tale offers an ironic form of escape for the reader: after 
experiencing the inferiority of man in a Lovecraft story, even the most mundane human experience in the real world seems important by contrast.

While "The Dunwich Horror" creates an archetype for the weird tale as contemporary myth, the story also speaks of the tradition of myth itself. This textual code of myth and legend forms an important part of the story and places myth within a cultural context.

The tale, which reads like a legend, points to the past and "old legends [that] speak of unhallowed rites and conclaves of the Indians" (DH 157), contrasting that previous age with "our sensible age." The text develops the Dunwich legend from the time of the Indians to the present, with examples of these ancient myths. Hoadley's sermon, the text of which was printed in Springfield and still exists, speaks of the evil in 1747 , and newspaper accounts of the Whateley's (DH 165) bring it up to date. The legend of the whippoorwill as presented by Lovecraft ironically presents the duality of myth in miniature. While the inhabitants of Dunwich consider the bird to be demonic as it lies in wait for the souls of the dying, more traditional New England folklore nicknames the bird "Pope, by reason of its darting with great swiftness from the clouds to the ground and bawling out 'Pope'...." (Botkin 192). Depending upon the specific legend, the bird is seen as either a friendly creature that warns of ominous storms, or as "a spy, an agent of antichrist." Birds in 
general are considered "mystical" creatures (Wedeck, 57) and have become a part of the modern horror tale (the most famous example, of course, being the $1963 \mathrm{Hitchcock}$ classic).

Lovecraft attempts to establish a contrast between myth and reality by contrasting the old and the modern. The legends are depicted as "ancient lore" (159), tales that are "obsolete and ridiculous; because they come down from very old times...." (158). Yet Lovecraft contradicts his disbelief of ancient myths, both in the use of the Charles Lamb epigraph and in the text of "The Dunwich Horror". No sooner does the narrator dismiss the ancient legends than he tells the "truth" of the Dunwich horror-a truth that makes the ancient legends appear tame by comparison. The town has a history of horror that culminates in the whateley twins, but, like Cthulhu, the horror predates mankind. The town, then, can be seen as a symbol of the weird tale, which has evolved from ancient legends of ghosts and vampires to modern and more realistic terrors of the space age.

On a cultural level, Lovecraft's tale provides some insight into myth and folklore, and places horror in a sociological perspective by examining cultural taboos. since myth and folklore often help express and define a culture's taboos, the textual and cultural codes of "The Dunwich Horror" work together to highlight this theme. In "The Dunwich Horror", Lovecraft explores the idea 
of the "forbidden," both in culture and in literature. From the very beginning of the tale, the town is portrayed as forbidden-- should one take the "wrong fork" in the road and encounter the inhabitants of that village, "one feels somehow confronted by forbidden things..." (156). Unlike the forbidden knowledge that Lovecraft alludes to in many of his stories, these earthy and concrete taboos are symbolized by the inhabitants of the village, who are "repellently decadent, having gone far along that path of retrogression" to have "come to form a race by themselves" (157). This notion (which also appears in "The Shadow over Innsmouth" and other tales) alludes to incest and inbreeding that have, through a perverse form of reverse evolution, created an inferior race of beings that are, perhaps, not completely human.

According to Levi-Strauss, "The incest prohibition is... the basis of human society; in a sense, it is the society" (19). The town of Dunwich, through its isolation, inbreeding, and ignorance of cultural norms, has divorced itself from society and entered the world of the forbidden. Using the idea of the forbidden as a basis, we may analyze its implications using the "semantic rectangle" of Greimas : 


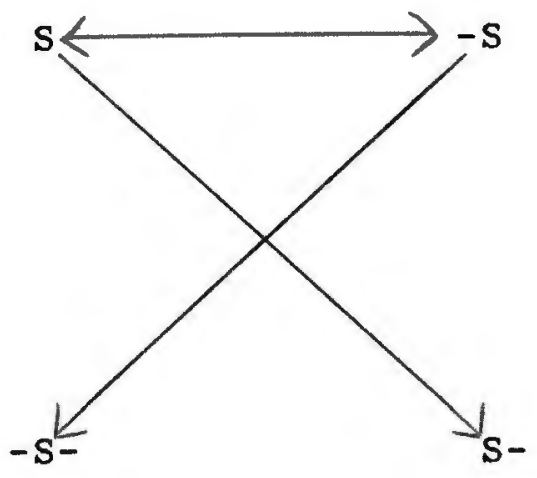

When applying this rectangle to marriage customs (Jameson 163-164) S stands for normal sexual relations between husband and wife, $-S$ stands for abnormal or forbidden relationships (i.e. incest), $s$ - stands for relationships that occur outside of the legitimacy of marriage, and -S"may be understood as the simple negative of the abnormal, forbidden relations, or in other words, those sexual relationships which are neither abnormal nor explicitly forbidden: e.g., masculine adultery." (164) As Jameson has observed, "the codification of marriage law... implies a notion of the forbidden in its very structure" (164).

The town of Dunwich can be represented by $-S$ in the traditional model, and is thus, considered abnormal and forbidden. However, applying the rectangle to the society of Dunwich, which does not forbid incest and inbreeding, turns this typical model on its side. 


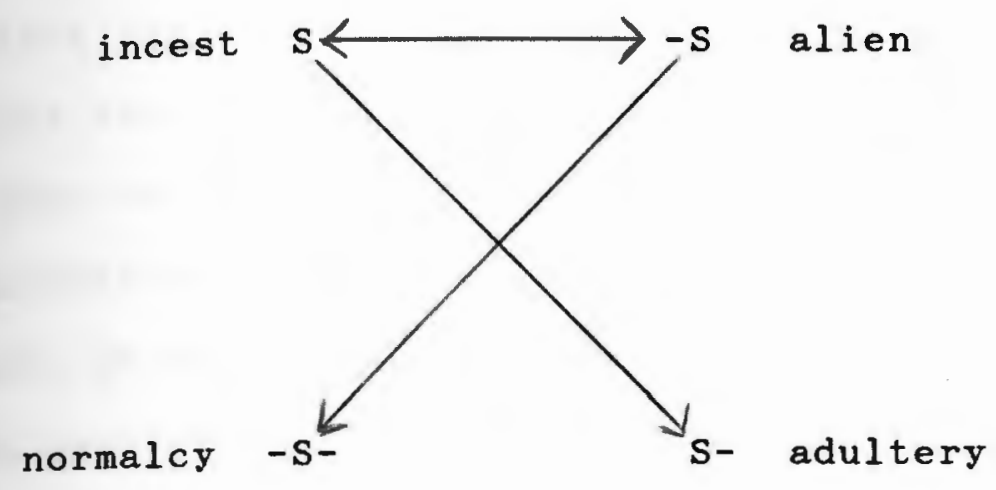

In Dunwich, the Whateley twins symbolize the forbidden $(-S)$, since they are the product of forbidden relations with alien life forms. To the inhabitants of Dunwich, sexual relationships become a form of masturbation; their incestuous relations, from a cultural point of view, are relations with themselves. This desire for "sameness" creates a new definition of homosexuality for them as they symbolically seek partners who are the "same" as themselves. Lavinia Whateley thus gives a new definition to heterosexuality as relationships with a different and alien life form. Since inbreeding is the norm, abnormality is pushed to the limits, giving heterosexuality new and perverse meaning in this twisted society. Furthermore, in a society that accepts incest, this society of self-professed witches and devil-worship, sex with the devil himself might very well be considered normal. In exploring the idea of forbidden acts, Lovecraft 
reverses the normal cultural definitions of taboo, even as he reverses the mythology that defines them. In establishing the new limits of the forbidden, he establishes the diametric opposition between human and alien. When we consider Levi-Strauss's statement that the incest prohibition is the basis for society, the inhabitants of Dunwich have blurred the very definition of the human species. As Burleson has observed, the Whateley's have formed a "bridge" between humanness and alienness, just as the town of Dunwich is linked to "normal" society by bridges of "dubious safety." The deformed half-normal inhabitants of Dunwich, the product of abnormal relationships, represent a linkage between the town and the outside world. And the Whateley monsters, the product of abnormal relationships as defined by Dunwich standards, symbolize the linkage between the earth and the hideous terrors of the universe. Since bridges separate as well as link, the inhabitants of Dunwich-- and of the earth-- are saved by the failure of the mythic hero, and not by any heroic actions of man.

In addition to the textual/cultural code of myth and legend, "The Dunwich Horror" also contains a textual code that speaks to the process of reading, of decoding a text. Donald Burleson has examined the motif of cryptanalysis as "our inability to 'read' the universe" and as "an allegory for such things as the text hide[ing] beneath its own surface workings" (130). He goes on to ask the question of 
"why Wilbur even kept a diary, since a polyalphabetic encipherment would be something that not even he could casually peruse, or read at all without tedious application of the key."

Wilbur's diary, seen in textual terms, symbolizes the author's drive to record his text, and the code represents the efforts of the reader to unravel this narrative and find meaning. The complexity of the code and the fact that even Wilbur must decipher it in order to recall what he has written demonstrates the notion that the author of a text may not even fully understand the meaning and significance of his narrative. While the deconstructionists may claim that the text will never be completely decoded (and, as Burleson says, Professor Armitage never does fully comprehend the significance of the text), Lovecraft assures us that writers will always write, and readers will always read, strictly for the what Barthes has termed jouissance, or the pleasure of the text. Lovecraft assures us that the "literature of cosmic fear... has always existed, and always will exist...." (D 367), because "No amount of rationalism, reform, or Freudian analysis can quite annul the thrill of the chimney-corner whisper or the lonely wood." ( $D$ 366) In short, the mythology of fear is an archetype that is as old as narrative itself, and, according to Lovecraft, a legitimate form of literature. As we will see in the next chapter, this mythology is often best expressed by that which is not said, rather than that 
which is made explicit. 
9. "The Unnamable":

The Power of Language

"The Unnamable," written in 1923, is one of several Lovecraft tales that refer to "nameless" things. As Joshi has noted by comparing passages from "The Unnamable" with those from "Supernatural Horror in Literature," the short story is "a scarcely veiled metaphor for Lovecraft's repeated assertion that since art is a 'treatment of life' (SL II, 144) and fear enters (occasionally) into our lives, the weird tale must be art" (Decline 117). Indeed, Lovecraft's defense of the weird tale through a textual code is commonplace in his fiction, as we have already seen in "Pickman's Model" and in others.

Lovecraft not only defends horror fiction, but, in many ways redefines it by moving it away from its Gothic traditions and into the modern age. As we have seen in "Dagon," and "The Shunned House," Lovecraft was aware of the Gothic tradition and realized its limitations. As he says of his monster in "The Unnamable":

nobody but a cheap sensationalist would think of having it grow up, look into people's windows at 
night, and be hidden in the attic of a house, in flesh and spirit, till someone saw it at the window centuries later and couldn't describe what it was that had turned his hair grey. (D 203)

"The Unnamable" must be considered one of Lovecraft's most textual stories since the protagonist, Randolph Carter (alias, Lovecraft himself) is a writer of weird tales who discusses his craft-- and the idea of the supernatural-with his companion. Lovecraft uses this story to poke some fun at himself and his work, as he says that

"unmentionable" things were "quite in keeping with my lowly standing as an author" (200). Yet despite this harmless fun, Lovecraft was only too well aware of the standing of "weird" writers in the literary community.

Beneath the obvious defense of weird fiction lies a discussion of the power of language itself. The premise of the story, that some horrors simply cannot be named, speaks to the very nature of language as the tale immediately establishes a symbolic code of namable vs unnamable, logic vs imagination. Joel Manton, the protagonist's friend, argues that "nothing can be really unnamable. It didn't sound sensible to him." Lovecraft, through the persona of Randolph Carter, assures his friend that "Common sense... is merely a stupid absence of imagination and mental flexibility."

This dispute is not really a debate over the reality 
or unreality of supernatural phenomenon, a fact that Carter acknowledges: "I knew that Joel Manton actually half clung to many old-wives' superstitions which sophisticated people had long outgrown....". It is, instead, a discussion about whether such phenomenon can be described and named.

The idea of naming is the foundation for modern linguistics and for structuralism and semiotics, which recognizes the intimacy between language and thought. As Ferdinand de Saussure has said: "In language, one can neither isolate sound from thought nor thought from sound" (157). According to this theory, to name an object, one must be able to think of or imagine it, and to comprehend it in some way.

Naming something gives one power, and, thus, names are an important part of mankind's social construct. Parents choose their children's names with care, and, in the mythology of the supernatural, names are an important part of casting spells (Wedeck 276). Indeed, the name of God is said to be unknowable, a theme used by Arthur C. Clarke in his short story, "The Nine Billion Names of God," where a futuristic religious cult used a supercomputer to list every possible name of God. Once the correct name is listed, God reasserts his power by destroying the world!

On the other hand one cannot name what one cannot imagine and fully comprehend-- hence the impossibility of mortals being able to "name" God. According to Lovecraft's view, there are things in the universe that are 
"unnamable"-- that cannot be imagined, described, comprehended, or understood. We have seen this idea at work in "The Colour out of space," where it is impossible to name a color that is totally alien to the human experience, outside of the known spectrum. This concept of cosmic horror as defined in "The Colour Out of space" forms the basis for the idea of something being "Unnamable." The vastness and complexity of the universe and its ability to defy man's understanding of it accounts for one aspect of something's being unnamable. When Manton finally sees the ultimate horror and admits that it cannot be described, he is, in essence, admitting that mankind can never understand the universe, that all attempts to formulate a universal theory are in vain. This admission also neutralizes man's power over the universe, since he can only control what he can understand-- and name. This inability to name something underscores man's insignificance.

Another aspect of the inability to name lies in the inadequacy of language itself. Lovecraft, like all writers, understood the weakness of language. Although, as De Saussure has said, the sound and the thought cannot be isolated from one another, poststructuralist theory realizes that attempting to substitute the word for the actual object creates "slippage" which leads to a deconstructing of the text. If slippage occurs in traditional fiction, it is magnified in works of pure 
imagination, where the actual "object" exists only in the mind of its creator.

Horror and "weird" fiction, of course, rely upon this slippage as part of their premise. The best horror fiction never fully describes the ultimate evil, but leaves it to the reader's own imagination to recreate. This idea of leaving the monster "unnamable" keeps the reader from gaining power over it. Once it is recognized as a vampire, for example, the reader can immediately classify it, compare it to all other fictional vampires, and know how to control it-- an oaken stake through the heart should do the trick. As Lovecraft said:

Crude writers use the old trick of calling a hidden horror 'too monstrous to describe' merely as an excuse for not forming any clear picture of the alleged horror themselves. But the skilled author who knows what he is doing can often hint a thing much better than it can be told. (SL III $174)$

Because they cannot be named, Lovecraft's monsters cannot be catalogued, controlled, or defeated. (Interestingly enough, a recent book called S. Petersen's Field Guide to thulhu Monsters has attempted to illustrate, classify, and describe Lovecraft's creations in intricate detail, perhaps in an attempt to gain control over these mythical creatures; however, even this volume contains no 
description or illustration of "The Unnamable".)

When Lovecraft does name his monsters in his Cthulhu tales, the names still defy understanding because they are not derived from any known language. "Cthulhu" is virtually unpronounceable and defies the code of language as we know it. Although it is named, it remains, like God, essentially unnamable since the name is nothing more than an approximation.

In acknowledging the necessity of "slippage" in horror by leaving his monster unnamed, Lovecraft also acknowledges his frustration with language, since it cannot replicate the terror that the imagination can create. Since fear depends upon a lack of power, the language of terror fails by being too powerful. Lovecraft realizes that only through a lack of language, in not naming, can the ultimate terror be described. Because of the power it gives mankind to understand and control the universe, language, by its very nature, fails in the realm of terror. Lovecraft the horror writer realized that he must work with flawed tools. Horror, in effect, deconstructs language: by demonstrating the power of language in understanding the universe, the weird tale reveals the inadequacy of language, which fails because of its power. 


\section{PART THREE}

LOVECRAFT'S VISION OF TRUTH:

FANTASY AS A MEANS OF UNDERSTANDING REALITY 
PART THREE

Lovecraft's Vision of Truth:

Fantasy as a Means of Understanding Reality

In Part Two we examined Lovecraft's vision of horror and how he has crafted fantasy into a unique and different form of weird tale. As we have seen, his fiction has been a majór influence on the development of modern horror as a genre by merging science fiction with terror to create the genre of cosmic horror. This new genre has, in effect, taken mythology into the space age, creating a type of scientific horror that is able to touch the collective subconsious with its realistic and scientific rationale.

In Part Three I will show that Lovecraft used horror and fantasy as more than just devices to create terror for readers of the pulp magazines of the time, but as tools to express his vision of truth and philosophy, which is really a cosmic reflection of the naturalism of Hemingway and other early twentieth century American writers. Lovecraft used fantasy as more than merely an end in itself, but as a means of looking at reality in a different and unusual light as he metaphorically casts his shadows upon what we perceive as truth. Although he does not attempt to delve 
greatly into the intricacies of individual human existence, as do Faulkner and Joyce, who privilege characterization, Lovecraft does attempt to explain humanity in the greater context of the universe in which it exists. By demeaning individual worth, he uses the fantastic as type of artificial light with which to examine the cosmos and man's place within it.

In this section we will examine six stories in detail and explore how Lovecraft's work goes beyond mere horror by looking at man and his environment through the touchstone of fantasy. In some cases, this exploration is on the psychological level, as in "The Outsider," where the narrator discovers a terrible truth about himself. In some cases, the fantasy may reveal insights into Lovecraft's personal and realistic fears, as in "The Haunter of the Dark," which discloses the author's growing concern with his deteriorating financial condition. Finally, in "The Shadow out of Time," fantasy will explore what Lovecraft saw as cosmic truths about the nature of the universe and human unimportance within the overall scheme of things. As we have already seen, an underlying thread of truth and knowledge-- and their destructive potential-- pervades the work of H.P. Lovecraft. The stories, then, not only reveal what Lovecraft considered to be truth, but also reveal the destructive nature of this truth, on both the psychological, personal, and cosmic levels. In a strange sort of textual code of its own, the horror story becomes a 
metaphor for the quest for knowledge-- even though we know it may not be pleasant, so does it attract and seduce in its own perverse way.

As we will see in Part Three, Lovecraft realized the destructive potential in even the most innocent pursuit of truth and knowledge. Yet his fiction makes no attempt to stop man in his reckless pursuit, since it is obvious that he is doomed to seek knowledge at any cost. And, as we have seen in "The Colour out of space," man's most painful and terrible revelation may be the discovery that the secrets of the universe cannot be known, that they are beyond man's capacity to understand.

To Lovecraft, truth is spelled with a capital "T.": it explores the nature and creation of the universe itself. Since he sees truth-- and its fearful potential-- as a cosmic phenomenon, it is only natural and proper that it be expressed on a cosmic scale. Science fiction and horror are the logical tools with which to accomplish this.

Lovecraft crafted the weird tale to suit his verson of truth and express his philosophy of the universe. While the fantastic monsters do not exist on a literal level, the shadows they cast metaphorically reveal the silhouette of a realistic and disturbing universe where man is but a pawn-a view of the universe that is remarkably similar to that expressed by other major authors of the era, but on a much more cosmic scale. 
10. Charles Dexter Ward:

The Prototype Protagonist

Although Lovecraft is remembered primarily as a writer of short stories, most science fiction critics believe that Case of Charles Dexter Ward could have been successfully published as a novel had Lovecraft offered it for sale. At 48,000 words, it was the longest tale he ever. composed; ironically, although publishers asked him for a book-length manuscript, Lovecraft never got around to typing the story, let alone submitting it.

The Case of Charles Dexter Ward resembles "The Call of Cthulhu" in its narrative focus, which employs a "Chinese Box" type of narration. While the Cthulhu short story uses a textual point of view with the story based upon a written text or diary, the Charles Dexter Ward story does employ an omniscient narrator. The narrative focus, however, changes as information about each of the story's major characters and events is revealed. The structure, in fact, consists of several mystery stories within a mystery story, each of which must be solved before we can understand the whole. The overall effect creates a "historical" point of view, with the reader taking on the role of the historian trying 
to learn the answers to the mysteries of the past.

The first narrative point of view introduces the overall mystery of Charles Dexter Ward and develops a portrait of him. This section (MM 107-117) essentially provides a history and biography of him during his "normal" period, before he became obsessed with his ancestor, Joseph Curwen. Ward, a blueprint of the typical Lovecraftian protagonist, is a gentleman scholar, an introspective researcher consumed with a search for truth. A "scholar and an antiquarian," he, like Lovecraft, was an "omnivorous reader" who spent much of his time walking the streets of his beloved Providence:

One may picture him as he was in those days; tall, slim, and blond, with studious eyes and a slight stoop, dressed somewhat carelessly, and giving a dominant impression of harmless awkwardness rather than attractiveness." $(112-113)$

Like most of his protagonists, ward presents a thin disguise for Lovecraft himself.

In the next section of the novel (beginning with page 117) the narrative voice travels back to the 18 th Century and examines the legends of Joseph Curwen. Yet the narrative voice assumes a certain authority as it observes Curwen's life through the eyes of his 18 th century neighbors, giving the account a historical rather than a 
mythological point of view. Clearly, the narrative voice knows the answers to the mystery of Curwen as it recreates vivid detail with dialogue and even thoughts of those involved.

The mystery of Joseph Curwen is revealed in a most interesting and unusual way. After introducing Curwen as the subject of "rambling legends," the narrator sets about investigating the veracity of these legends. To do so, he introduces several 18 th century characters, most notably Ezra Weeden, who takes on the role of a detective investigating Curwen's activities. As we learn the details of Curwen's life, the narrative focus gradually changes to encompass the point of view of Charles Dexter Ward, as he rediscovers the truth about his ancestor through his investigation of Weeden's findings.

Once Ward learns the truth, the situation becomes even more complex. Ward-- and the narrator-- conceal the truth from the reader (at least directly, though the observant reader will undoubtedly begin to assemble the pieces of the puzzle). Another detective is introduced in the persona of Dr. Willet, who investigates Ward. Willet, perhaps the closest character to a true Lovecraft hero, ultimately solves the mystery and vanquishes the evil. Yet the interest in the story is not the solution so much as the search for it. As Leiber has said, it is "the device of fonfirmation rather than revelation" (56).

By the time the novel is complete, the narrative focus 
and point of view are probably as complex and potentially confusing as can be found in literature. The narrator investigates Ward who researches Curwen by learning about Weeden who, also investigates Curwen; once this initial truth about Curwen is learned, Ward changes, and is, in turn, investigated by Willet who must retrace Ward's steps in researching Curwen.

If, as Penzoldt has asserted, "Lovecraft's tales are nearly always perfect in structure" (69), then this complicated point of view must have a justification. As confusing as it may appear in outline form, the structure does works in this "fable about the problems of history and... warning about the dangers of historical research" (St. Armand 174-75). While "The Call of Cthulhu" has a textual point of view, Charles Dexter Ward has a historical point of view. In other words, in order to understand the text, the reader must perform the same type of activities as the historical researcher. The reader becomes a historian as he learns about Ward, reads about his genealogy, and unearths the secrets of his past. The astute reader, like the historian, is encouraged to put the separate pieces of the puzzle together to form a complete picture. After the reader-as-historian learns the truth, the ending, as Leiber says, becomes a confirmation.

While the novel may, indeed, say that "it is dangerous to know too much, especially about one's own ancestors" (St. Armand 178), it also puts the reader in the 
uncomfortable position of being the one who has learned too much. While Ward has learned an awful truth through reading and research, the reader of the novel has done likewise by rediscovering this knowledge. Since much of the information is presented in the form of historical documents such as diaries, newspaper clippings, and genealogical records, the reader gains a sense of reading history rather than fiction. And while the Curwen story might be mentioned as legend, the omniscient narrator is careful to separate fact from folk tale, as any good historian should.

While highlighting the theme of the dangers of learning too much about the past, the historical point of view in Charles Dexter Ward also introduces a textual code involving books and the power of language. Lovecraft saw books as a means to truth; however, the greatest truths lie between the covers of the most "forbidden" books. The Gre of Charles Dexter Ward portrays books and language as a double-edged sword, capable of imparting great knowledge and truth while also having the potential for great danger.

Lovecraft personifies the dual nature of books in his characters, who represent the good and evil potential of truth and knowledge. Curwen, "owner of the best library in Providence" (MM 120), symbolizes the dark side of knowledge used for evil and selfish ends. He seeks truth as a source of power and immortality, without regard for the consequences of such knowledge. 
There is a fine line between pursuit of knowledge for its own sake and pursuit of knowledge for selfish motives. While Curwen obviously seeks knowledge for his own ends, Charles Dexter Ward originally seeks knowledge to satisfy his curiosity and thirst for truth. Ward, the innocent, becomes so obsessed with truth that he cannot see its destructive potential. His quest ultimately destroys him and threatens human civilization as he meddles with powers far beyond his control.

The parallels between Charles Dexter Ward and "Herbert West-- Reanimator" are obvious. While Ward symbolizes the destructive potential of knowing too much about the past, Herbert West personifies the destructive potential of science. West, like Ward, begins his research as an innocent, believing that he can help mankind by learning how to bring the dead back to life. As he continues his experiments, however, his quest becomes more personal-his ego leads him to murder and moral degeneracy as his search for knowledge degenerates into a vehicle to power and fame. West depicts the destructive potential of science when not held in check by ethics and, in fact, predicts many of the ethical dilemmas that science has produced today. While Lovecraft may not have specifically foreseen the development of the atomic bomb, genetic engineering, and artificial means of prolonging life, he was concerned that science, in its tireless quest for knowledge, has little time for considering the ethical consequences of its 
discoveries.

In "Facts Concerning the Late Arthur Jermyn and His Family", Lovecraft warns: "Science, already oppressive with its shocking revelations, will perhaps be the ultimate exterminator of our human species..." (D, 73). In this story, Lovecraft combines the destructive potential of Ward's "knowing too much about the past" with the danger of West's scientific discoveries. Arthur Jermyn, an anthropologist, personifies both historian and scientist as his search for truth leads him to a discovery about his ancestors. Indeed, Jermyn represents an obvious metaphor for Darwin's theories as he discovers that he is descended from an ape. Such knowledge, while it may represent truth, is not always healthy for the human animal, and Jermyn destroys himself. The theories of Darwin, Einstein, and others have had a powerful effect upon the human race at large; as scientific knowledge has increased, the importance of man in the universe has decreased in inverse proportion. Mankind is no longer the center of the universe, and Lovecraft, who was personally disturbed by his perceptions of man's insignificance, recognized the destructive potential of such knowledge on the human psyche.

The Case of Charles Dexter Ward, "Herbert West-Reanimator," and "Facts Concerning the Late Arthur Jermyn and His Family" not only show the destructive potential of knowledge, but question man's right to obtain such 
knowledge in the first place. In the Lovecraft canon, the most powerful truths are of the "forbidden" variety, as symbolized by the "dreaded Necronomican" which is kept under lock and key in the Miskatonic University Library. At first glance, one would believe that Lovecraft condones censorship of "forbidden" knowledge as necessary to the mental and physical well-being of mankind. Captain Whipple and the Providence patriots who put an end to Joseph Curwen could not "ever be induced to say a word concerning it" (MM, 146) and deliberately set about on "The deliberate effacement of every memory of the dead man...." (147). Yet, while their motives were pure, there was "something frightful" in the care with which they "destroyed every scrap which bore the least allusion to the matter" (146).

Although Lovecraft, like his protagonists, knew that knowledge could be harmful and destructive, neither he nor they gould do anything about it. Lovecraft admits his "insatiable desire for knowledge" (SL I 31) and "that simplest yet most exalted attribute of our species-- the acute, persistent, unquenchable craving TO KNOW." (SL I 61). He, like his protagonists, continued to read and learn, and even to share accumulated knowledge with others-- by writing. Lovecraft's quest for knowledge led him to the painful belief of man's insignificance in the universe; yet while he instinctively recognized the harmful nature of this knowledge, both his personal 
correspondences and his fiction testify to the fact that he never censored this knowledge from others.

The Case of Charles Dexter Ward dramatizes man's Inability to censor knowledge, even when he wishes to do so. Joseph Curwen, like many of Lovecraft's characters, keeps a diary, despite the fact that it may-- and often does-- lead to their undoing. Curwen cannot keep his terrible knowledge to himself, but, like Wilbur Whateley, leaves behind a coded diary for someone else to decipher. When John Merritt visits Curwen's library and discovers a disturbing underscored passage from Borellus, he not only commits the lines to memory, but writes it down in his own diary and even attempts to recite it to his friend (122).

Perhaps the most interesting example of failed censorship involves the attempt to delete any mention of Curwen's name from the town's records. A town clerk carefully pastes together two pages from a record in an attempt to obliterate the name, then painstakingly renumbers the pages of the record to cover up this censorship. As Gatto has observed (85), one must wonder why the clerk didn't simply rip the page from the book and destroy it. While Gatto suggests that Lovecraft may have been having fun with the Protestant ethic and the impossibility of destroying public property, I believe the answer goes beyond this. Mankind, once he has obtained knowledge, simply cannot destroy it. No sooner could the clerk have ripped out a page from the town records than 
Einstein could have kept $E=M C 2$ to himself once he discovered it.

If knowledge has power, that power is expressed in the form of language. As I have said previously, there is an inherent power in being able to name things. Language gives man the power to control his universe; he cannot control what he cannot name-- hence, the "nameless" monsters of the Lovecraftian world.

In Charles Dexter Ward language takes on a magical power in the form of spells and incantations. Knowing the right formula-- the right words- can either raise or destroy the most terrible powers of the universe. Words are the very key to life itself. As we have seen in a number of Lovecraft's stories, speaking, narrating, and writing mean life.

At the very ending of Charles Dexter Ward, Willett has learned the formula that will destroy Curwen forever. Even as Curwen begins his own incantation, willett cuts him off with one that is more powerful:

At the very first word from willett's mouth the previously commenced formula of the patient stopped short. Unable to speak, the monster made wild motions with his arms until they too were arrested. When the awful name Yog-Sothoth was uttered, the hideous change began. It was not merely a dissolution, but rather a transformation or recapitulation. (MM 234) 
Joseph Curwen, evil incarnate, is destroyed by words. 
11. "The Outsider":

The Terror Within

While Charles Dexter Ward and the Mythos stories depict human insignificance in the universe in cosmic terms and deal with the horror of learning cosmic truths, Lovecraft also examined the destructive nature of self-discovery on a more personal, psychological level. Perhaps the best example of this theme can be found in a short story titled "The Outsider," written in 1921. In this Poe-esque tale, an unnamed first person narrator tells the story of how he climbs from the entombment of a dark castle in search of light, and ultimately learns that he is a reanimated corpse. (Although Mollie Burleson speculates that the Outsider may have been a woman, I believe that the first line of the story ["unhappy is he..."] coupled with the fact that females in Lovecraft are a rare occurrence makes it safe to call the narrator a "he.")

Since this tale is, by its very nature, a mystery story of sorts, with the narrator ultimately discovering the truth about himself, I will begin my analysis by examining the devices that form the hermeneutic code of the 
story. The story opens with a cryptic first paragraph describing a childhood of "fear and sadness" that seems pleasant and happy compared to the memories of the narrator when his mind "threatens to reach beyond the other" (DH 46). This "other" is purposely left vague, immediately enticing the reader into the story. The next paragraph Introduces additional enigmas as the narrator explains that he doesn't know where he was born or who cared for him. This lack of knowledge coupled with the Gothic connotations of darkness, cobwebs, shadows and towers creates a mood of dread and anticipation for the horrors that lie ahead. Yet, a's the narrator attempts to move away from this atmosphere of terror, he ultimately discovers an even greater terror existing within himself.

This story, which may be one of the most deeply psychological of all the tales in the Lovecraft canon, is also one of the most allegorical. The narrator's quest for light and vitimate discovery of a hideous and painful truth underscores Lovecraft's concept of the destructive power of truth and knowledge. And, if "The Outsider" is really meant to be interpreted as a dream, as Fulwiler has suggested, the story also illustrates the power of the imagination in discovering truth.

In this tale, the symbolic opposition between light and darkness and the quest for light represents mankind's destructive search for truth and self knowledge. From the very beginning of the story, the narrator, like a moth near 
a candle, is obsessed with a "longing for light" that "grew so frantic that I could rest no more." This is an interesting reversal of the search for truth in "Pickman's Model," where the artist figure seeks truth in darkness, in the darker reaches of his mind. The outsider "resolved to scale that tower, fall though I might; since it were better to glimpse the sky and perish, than to live without ever beholding the day."

The action code of this tale is also completely reversed from that of "Pickman's Model." Where Pickman finds truth and Elliot finds terror by descending into the earth, the Outsider finds truth and terror by ascending. Indeed, his long, arduous trek upwards through the inside of the tower resembles a journey through the birth canal as he leaves his stale womb and seeks rebirth. In a mockery of labor and delivery, the Outsider emerges into the light of the full moon, knowing not "who I was or what I was, or what my surroundings might be" (DH 49).

Looking at his search for truth from a psychological perspective, we see the narrator as a newborn infant who has just entered a strange, frightening and wondrous world, filled with light and discovery. His first glimpse of truth-- that he has climbed to the surface of the earth from somewhere below-- shocks him but does not cure his "longing for light." At this point the Outsider, like the newborn, sees the universe merely as an extension of himself. Even as the growing child must discover the 
painful truth that he is but a small part of the universe, so does the Outsider discover his place. Like the child, he learns that humankind is not always beautiful and godlike but is often hideous and grotesque, even in the eyes of his fellow man. While most individuals accept this painful reality, the Outsider, cannot face the truth and flees back into the sanctuary of his decayed womb.

Ironically, truth is originally portrayed as happy as the narrator remembers colorful pictures from some of the molding books in his possession. Yet even then this happiness is undercut with irony at the realization that there might be a price to pay: "I... was determined to gaze upon brilliance and gaiety at any cost." The narrator, in discovering the truth about himself, learns that truth itself is painful and destructive. The brilliance of truth hurts his eyes with its light, and he discovers "that light is not for me."

Yet despite the pain that accompanies truth, the narrator has no regrets. Indeed, for him it is better to "glimpse the sky... than to live without ever beholding the day." In the end, he is satisfied, despite his pain: "I am strangely content, and cling desperately to those sere memories..." This idea reflects what Lovecraft thought, as he tried to deal with his own personal truth as best he could: "In ceasing to care about most things, I have ceased to suffer in many ways. There is a real restfulness in the scientific conviction that nothing matters very 
much..." (SL I 87).

The cultural code also comes into play in this instance, as the outsider discovers that he is "different" from what society considers "normal." Anything different is automatically shunned: "... there descended upon the whole company a sudden and unheralded fear of hideous intensity, distorting every face and evoking the most horrible screams from nearly every throat. Flight was universal..." (50).

Lovecraft was an elitist in many respects and saw himself as separate from what he termed "the herd" (SL I 211). An avowed atheist since childhood, he undoubtedly felt isolated from his fellow man, and turned inwards to the imagination in order to find truth. This, coupled with his mother's belief that her son was "hideous" and "ugly" (Faig 33 ), lends certain autobiographical elements to the story, since Lovecraft knew first hand what it was like to be "different."

As Peter Cannon has suggested, Lovecraft was a "Literary Outsider," in that he worked in a genre that was not respected as Iiterature. He recognized that horror was for the few and not the many, and gave up hope of fame or fortune from his writing: "... it has really ceased to be of any interest to me whether anyone reads my junk or not... I want the fun of writing it." (SL III 235). Yet as a writer of the "weird tale," Lovecraft was also concerned with horror as a form of truth (D 365 ). 
Since truth is a painful and potentially destructive element, Lovecraft equated truth with horror, and his ultimate truths are depicted as the most hideous horrors. As both Cannon and Gatto have suggested, Lovecraft's personal search for truth may have revealed the terrible knowledge that his father died of syphilis. Based on the fact that so many of Lovecraft's protagonists are involved in genealogical research ("The Picture in the House", "The Shadow over Innsmouth", and The Case of Charles Dexter Ward are the obvious examples), this premise may hold some validity and may help to account with Lovecraft's preoccupation with forbidden knowledge. This may explain why so many of his tales deal with what Cannon calls "hereditary degeneracy and the coupling of human beings with monsters" (1).

While at first glance, "The Outsider" may not seem to contain a textual or metalinguistic code, the story does address the nature of language and of 'storytelling. We are initially told that the Outsider lived in a world of books and "From such books I learned all that I know." It is interesting to note that although the narrator taught himself to read, he had "never thought to try to speak aloud." Since he never spoke he was symbolically unable to communicate even with himself. His search for truth, then, took on an external form, since it could not come from within. Had he recognized truth, he would not have been able to communicate it to others or to himself. 
Once the Outsider discovers truth, he speaks "the first and last sounds I ever uttered" (DH 51). Truth, by its very nature, forces communication, even if this communication takes the form of "a ghastly ululation" or, in the case of Lovecraft himself, a ghastly tale of terror. And, in fact, since the tale is told from a first person point of view, the Outsider does speak again as narrator of his tale. Even though he claims that "In the supreme horror of that second I forgot what horrified me" (DH 52), he does go on to remember and to describe his revelation by narrating his story. Again, truth demands to be communicated, regardless of the terribleness of its nature or its destructive potential. The Outsider cannot forget, but must metaphorically tell and retell the tale to whoever will listen, despite the consequences.

Finally, as Fulwiler has noted, one must be prepared to consider "The Outsider" as a dream, as is suggested by the epigraph from Keats" "The Eve of st. Agnes" that heads the story. This, according to Fulwiler, would explain the inconsistencies and illogic that make the tale irrational on a literal level. Seen as a dream, "The Outsider" represents the textual code of the subconscious, which is better able to grasp and accept truth than the conscious mind. The dream is another symbolic representation of the artist figure, the creative individual who dares to dream and to seek and express truth. While the rational man cannot or will not comprehend the obvious truth that 
128

surrounds him, the artist is able to discover truth and articulate it. In this case, the dream becomes a narrative vehicle to communicate truth.

"The Outsider" is probably one of the grimmest tales to come from Lovecraft's pen. Yet Lovecraft recognized that literature, as it seeks to unearth (pardon the pun) painful and often frightening truths, must, in turn, become painful, frightening, and depressing. Like Keats' Baron, the artist, to express truth, must break down the barriers to the subconscious mind and, in doing so, dream of "many a woe." 
12. "From Beyond":

Breaking Down the Barriers

"From Beyond," written in 1920, was "rejected by all the paying magazines" (SL IV 386) until finally printed by Weird Tales in 1938. This story has Crawford Tillinghast, another typical Lovecraft scholar, discovering the key to unlocking another dimension in the form of an electrical device that can transport man beyond the five senses. As Joshi has demonstrated, this story, one of Lovecraft's early efforts, was influenced by Hugh Elliot's Modern Science and Materialism (1919) (Decline, 84). According to Joshi, it is "one of the first stories both to present entities of an anomalous materiality and to present a philosophical justification for them." While this early tale certainly cannot be considered one of Lovecraft's best, it does offer an interesting insight into the nature of reality.

On a symbolic level, "From Beyond" sets up a bipolar opposition between the normal, three-dimensional world, or "here" if you will, and that which is "beyond." This opposition between here and beyond ultimately calls into 
question the nature of truth and reality itself. "We see things only as we are constructed to see them, and can gain no idea of their absolute nature" (D 91), Tillinghast says. Thus, mankind with his "five feeble senses" is incapable of seeing truth and cannot comprehend the universe around him. As philosophy this idea is harmless enough; however, the protagonist goes "beyond" merely thinking about the nature of truth, and, instead, attempts to find it first-hand. Through his "metaphysical researches" he finds "a way to break down the barriers" that keep man from seeing truth. This leads to a new and different perception of reality, a reality where ultraviolet light is now visible, as are "whole worlds of alien, unknown entities." Once the barriers have dropped, the known and the unknown merge together as one-- the bipolar oppositions between fantasy and reality, truth and ignorance, no longer exist.

The real issue in this story concerns the act of seeing, for the barriers keep man from seeing what is beyond. By removing the barriers, Tillinghast's machine leaves truth open for public view. Yet, he cautions that "in these rays we are able to be seen as well as to see." Truth, he acknowledges, has a double edge. Although it cannot physically hurt, looking upon it can destroy. "...it was seeing that made the poor devils scream so." Indeed, truth, is symbolized by the creatures from beyond, and, as Tillinghast warns, "My pets are not pretty." 
While Lovecraft, like his protagonists, spent much of his life in search of truth and knowledge, he realized that it was "not pretty." As we have seen, Lovecraft's idea of truth presented a world in which mankind was but an insect, tiny and insignificant. His own personal search for truth disclosed a history of mental illness in his family, and, considering his interest in genealogy, it is not unrealistic to assume that he may have learned that his father's death resulted from syphilis. Furthermore, he saw himself as physically ugly and incapable of earning a living for himself. Indeed, in Lovecraft's world, truth, as he perceived it, was painful to see.

In this world, then, it is no wonder that man erects barriers to shield himself from such painful truth, often believing what he wishes to believe. While these barriers protect most men from the destructive nature of truth, Tillinghast and other protagonists must break down these barriers and seek truth despite the consequences.

While on the symbolic level the opposition between the here and the beyond depicts the struggle between what man wants to believe and what is real, an analysis of the psychoanalytical code of this story offers an interesting look at the human psyche. Lovecraft, well acquainted with the theories of sigmund Freud, expresses ambivalence about him, calling him "one wise old bird [who] reduces all pleasure to the erotic" (SL III 259), then admitting that his psychological principles are "fundamentally important" 
(SL V 305). When examined on a psychoanalytical level, however, "From Beyond" speaks about the relationship between the conscious and the subconscious mind, especially in relation to truth.

The "here" of course, refers to the conscious mind, where man basically invents his own reality to suit himself. The conscious mind sees the world through the limited viewpoint of the ego, the "I", who, according to the tenants of The Pleasure Principle, is the center of the universe. This "I" of the conscious mind sees all of the world in relation to itself, and considers itself of supreme importance. This "I" is most developed in the newborn, who sees itself as the universe; everyone and everything in the world exists only to serve its needs. As the child grows, the "I" shrinks while the universe continually expands. In fact, the more one learns, the smaller and more insignificant one becomes in the overall scheme of things. While all men learn this truth to a degree, the scholar and the researcher are exposed to the "cosmic truth" of man's insignificance.

The "beyond" represents the subconscious mind, which, in its own instinctive way, often has a better handle on truth than the conscious mind. Freud demonstrated that man often buries unpleasant or painful truths within the subconscious mind, truths that can only be brought to the surface through hypnosis or other forms of therapy. Hence, the "Outsider" experiences his personal inadequacies 
through a dream, as we have seen.

of course, for an imaginative writer like Lovecraft, the subconscious mind also represents the creative part of the brain, the part of the mind that is allowed to indulge in fantasy and fiction. Yet while most men might regard the imagination as fantasy, Lovecraft saw it as a means of expressing truth through his art. His dreams and stories-his pets-- certainly "are not pretty." Yet literature seldom is, especially when it seeks to express truth. And, although his works include fantastic worlds and principles, Lovecraft considered truth a necessary part of art: "...no sane adult since 1910 could possibly wish life to be depicted as serious art in other than its true proportions" (SL III 106). Lovecraft wrote in 1930: "artificial aphrodisiac works of 'art' not grounded in nature or normal harmonics...are...pap and hokum, and emotional short-circuits and fakes. They are certainly not genuine art" (SL III 107).

While some might find it strange that Lovecraft, a self-avowed writer of the "weird tale," would preach realism in fiction, his tales, when divested of the fantastic trimmings, do speak of truth as Lovecraft perceived it. While neither he nor his readers realistically believed in the existence of Yog-Sothoth, the Fungi from Yuggoth, or the spawn of Cthulhu, these fanciful aliens symbolically personify the cosmic truth of man's insignificance. This naturalistic theme was presented in a 
more "realistic" way by many of Lovecraft's contemporaries-- Hemingway, Steinbeck, Eliot, for example. Lovecraft, however, saw the fantastic as a means of exposing reality, and perhaps no other author has expressed the theme of man's insignificance in quite the same way.

The "beyond," both as the subconscious and as fantasy does lead to a disturbing and potentially destructive truth. As Lovecraft understood, finding this truth requires one to "break down barriers," not only the barrier that keeps man from delving too deeply within his own imagination, but also the cultural and literary barrier that denies fantasy as a means to truth.

As Hume has demonstrated, both fantasy and realism are means of expressing truth:

Fantasy allows a dream-like overdetermination and condensation. The language of science (and, by extension, of realism) can achieve no such effect, for its whole thrust is to rely on a technical vocabulary in which a word stands for one universally acknowledged referent and no more. It aims to be unambiguous. Fantasy instead aims for richness, and often achieves a plethora of meanings. This polysemousness of fantasy is its crucial difference from realism as a way of projecting meaning.

According to Hume, fiction has developed in two 
separate and distinct patterns, fantasy and realism, which are often combined and merged in various ways. Only in the twentieth century, she argues, has realism been privileged. The explosion in twentieth century realism has, she continues, exhausted the possibilities for discovering truth through this means. Thus, she foresees greater return to fantasy as a means of expressing truth. This "Literature of Vision" presents alternate views of reality and "calls attention to the differences.... Creating a separate reality and calling attention to it is one characteristic of great, as opposed to merely competent, fiction" ( 82$)$

One of the frightening truths of Lovecraft's fiction, the "cosmic truth" that mankind, with his limited vision, is incapable of understanding the complexity of the universe, lends itself to exploration in science fiction and literature of the fantastic, which, in fact, attempts to endow the unbelievable with realism. Thus, Lovecraft's chosen genre, the weird tale, also serves as the most effective means of conveying his philosophy that the more man thinks he learns, the less he really knows. "[We find]... a radical increase in that element of unknowability which we always admitted" (SL III 224). The most terrible truth for man to face is the knowledge that he is quite blind to the truth around him, yet, without the fantastic device of Crawford Tillinghast, he is destined to remain blind. Furthermore, even were such a 
device available to "break down the barriers" it would only destroy man when he tried to use it.

The final barrier that Lovecraft breaks down in "From Beyond" is the barrier between science and philosophy, two vastly different fields that have traditionally come into conflict. Tillinghast, however, studies both science and philosophy, a dangerous combination to the "man of feeling and action." Science symbolizes man's logical quest for truth, for facts, figures, and tangible data. Philosophy symbolizes man's creative search for truth, his metaphysical searchings in religion, ethics, and even the nature of truth itself. Each of these fields, by itself, leads to a one-dimensional truth. Yet when the two fields are combined, a more three-dimensional-- and disturbing-truth results.

As mankind discovers more facts and figures, more scientific truths, this new knowledge impacts upon philosophy, as has been the case with Darwin, Einstein, and Freud. Analyzing these scientific truths in a philosophical context leads to a more "cosmic" truth, that continually deflates man's ego as it diminishes his place in the universe. Furthermore, as science advances, the barrier between science and philosophy will continue to crumble. In the five decades since Lovecraft's death, science has been forced to deal with a number of difficult and troublesome philosophical questions that perhaps cannot be solved, such as a patient's right not to be kept alive 
by artificial means, for example.

Even as Lovecraft recognizes the danger of breaking down the barriers, he also understands the inevitability of its occurrence. Lovecraft, like the narrator in "From Beyond," is "afraid of the cosmic truth." Yet he, like the narrator, has learned it, and must tell his story to others. For while the narrator claims he "did not tell much" of what he had seen, he, in effect, tells all through narration of the story. Likewise, Lovecraft, at first glance, may only seem to tell an entertaining story, without much substance. Yet even in an early and inferior tale such as "From Beyond," his story does tell all. 
13. "The Haunter in the Dark":

Cultural Code in The Two Hills of Providence

Although H.P. Lovecraft is probably the most significant literary figure in the history of Providence, he spent most of his adult life battling against poverty. His fiction was not commercially salable during his lifetime, except to a few small, modest paying pulp magazines such as Weird Tales, and he could not bring himself to write what he called "commercial works."

Lovecraft was born into a wealthy family and lived in a mansion until the age of 14 , when his grandfather's death and failed investments forced the first of several moves to more modest quarters. As the years went by, Lovecraft, who lacked any practical training that would enable him to earn a living, needed to do ghostwriting and revision in order to meet his expenses. He realized that he could never live on the meager earnings from his fiction, and spent most of his life worrying about money.

"The economic status of a man of my age without special training in the clerical or other industrial fields is not pleasant to contemplate," he wrote in 1936. "I seemed to think that sufficient money for ordinary needs 
was something which everyone had as a matter of course" (SL V 363).

"The Haunter in the Dark," originally published in Weird Tales in 1936 , contains a cultural code that symbolically depicts Lovecraft's fears of poverty by contrasting two sections of the city of Providence. The college Hill where Lovecraft was born and lived most of his life, depicts the comfortable, wealthy and scholarly culture that Lovecraft had known as a boy and had expected to continue forever. To him, leaving College Hill was equivalent to poverty, and in each of his progressive moves his priority was to find an economical home on what he called the "ancient hill." In dark contrast, Federal Hill shows the working-class culture of squalor and baseness that Lovecraft feared and despised. To Lovecraft, it is a world of immigrants and common people, totally alien to his way of life.

In 1935, the year that "The Haunter in the Dark" was written, Lovecraft still enjoyed a life of comparative ease that left him free to read, write, and study, even if he could not afford the luxuries of new clothes and gourmet food. His resources were steadily slipping away, however, and only his ghostwriting and revision work had saved him from poverty. Lovecraft harbored great fear that his funds would soon run out and he would be forced to seek employment, or move to more modest housing in another section of Providence. These fears of poverty symbolically 
come to life in "The Haunter in the Dark," as the "evil" of Federal Hill successfully invades College street.

The protagonist of the story, Robert Blake, is

patterned after Robert Bloch, a close friend of Lovecraft's who would go on to write the horror classic Psycho. Yet, as in most of Lovecraft's stories, the main character is a thin disguise for the author himself.

The fictional Robert Blake, a scholarly artist who shares Lovecraft's interest in the macabre, moves to Providence to write and paint. After creating several of his best known stories, Blake becomes fascinated with an ancient dark church on Federal Hill that he sees from his window. His fascination turns to obsession, and he finally sets out to locate and explore the church for himself. After becoming lost in the strange, maze-like streets of Federal Hill, he finds the church and ventures inside. His exploration of the dark structure ultimately sets loose an ancient evil that invades his comfortable College Hill home and destroys him.

The story begins by tantalizing the reader with the enigma of Robert Blake's death, then provides a background description of Blake's comfortable home on College Hill, which is actually Lovecraft's home on 66 college street. "It was a cosy and fascinating place, in a little garden oasis of village-like antiquity where huge, friendly cats sunned themselves atop a convenient shed." This culture is depicted by imagery of life, cleanliness and light. 
College Street, Brown University, and the John Hay Library evoke connotations of the scholarly, Ivy League life of leisurely study and affluence-- in short, the type of life Lovecraft had known in his youth and which he had expected would continue forever. Robert Blake seems unhindered by financial worries as he devotes his time to the scholarly activities of writing and painting, the perfect sort of life, in Lovecraft's world. College Hill, then, represents the culture of the scholar.

Yet, as Lovecraft's financial situation deteriorated, he feared that the days of his comfortable life were numbered. Thus, College $\mathrm{Hill}$ is immediately contrasted with Federal Hill, the other Providence, which Blake sees from his window. It is both extremely close, yet unreal. While College Hill is described as "the great eastward hill near the Brown University campus," Federal Hill is "the spectral hump," a diseased outgrowth of land. This world is dreamlike and nightmarish, at first, having nothing to do with Blake's reality. "Blake had a curious sense that he was looking upon some unknown, ethereal world which might or might not vanish in dream if ever he tried to seek it out and enter it in person." But as the story progresses, this world becomes frighteningly real until it actually invades College Hill.

Blake learns from his friends that Federal Hill is a "vast Italian quarter," a land of hard-working immigrants who have nothing in common with him. They are foreign to 
him, as they were to Lovecraft, and represent an alien culture that threatened to encroach upon Lovecraft's life, just as the Shining Trapezohedron invades Blake's world.

As the protagonist becomes more fascinated with Federal Hill, the place becomes increasingly sinister and realistic. The huge, dark church, in particular, begins to trouble him, haunting his evenings and making it impossible to write. (Interestingly enough, "The Haunter in the Dark" was the next to the last original piece of fiction that Lovecraft wrote; from its completion in 1935 to his death in 1937 , he was plagued by poor heath and his revision work and ghostwriting took up most of his creative time.)

Once Blake actually travels to Federal Hill, the images become more sharply focused. Even before he reaches the site of the dark church, he sees this other side of Providence as bleak, decayed, sagging and dingy. The streets and buildings are brown or black, with a conspicuous lack of any type of vegetation except weeds. It is an alien world of "dingy blue and white signs which meant nothing to him." Even as he fancies it "a dream-world never to be trod by living human feet," it is also a world of grim reality, a world of shopkeepers who work long hours, of housewives, and of children who play in the mud. This realistic world is, indeed, light years away from the world of Robert Blake-- and of Lovecraft himself. Yet it is a world that continues to move closer to both Blake's and Lovecraft's reality (it is the only one of his 
Providence stories to fictionally venture away from College Hill). Blake learns about its evil and accepts it, just as Lovecraft accepts the impending doom of his own situation. Yet neither Blake nor Lovecraft can do anything to change their respective situations.

The evil of Federal Hill, of course, ultimately

consumes Robert Blake as he helplessly watches from his apartment window on College Hill. "I am rather fond of depicting central figures as helpless in the face of oncoming horrors," (SL V 415) Lovecraft wrote in 1937, just a few weeks before his untimely death. Indeed, Lovecraft himself must have felt helpless in the face of poverty. suffering from ill health and with no career training or ability to write what he believed was commercially viable fiction, he could do little except watch and wait for the encroaching disaster that he felt certain would consume him. 
14. "The Whisperer in Darkness":

The Seductive Power of Knowledge

"The Whisperer in Darkness", written in 1930, represents one of mature Mythos stories and is generally considered one of Lovecraft's more powerful tales. Inspired by the discovery of the planet Pluto, this story postulates the existence of the Fungi from Yuggoth, an alien life form from the outermost planet that operates mining outposts on earth. These creatures, "could easily conquer the earth but have not tried to so far because they have not needed to" ( DH 218).

John Gatto sees "Whisperer" as "Lovecraft's dirty story" where "Wilmarth, Akeley, and the other humans... each had Eve's choice -- to listen to the serpent or ignore it" (61). According to this analysis, the alien beings represent a sort of pornography which preys on "the weaknesses of mortal curiosity" (61). From this, Gatto sees a theme of sexuality and censorship, and the necessity of protecting man from his own primitive sexual nature. While I believe that something can be said for this analysis in general, Gatto, in my opinion, is mistaken in the idea that sexual themes are the primary object of the 
story. Although Lovecraft considered erotic writing "a mere prying survey of the lowest part of life" (SL I 282), and "Whisperer" may metaphorically equate human lust with degeneracy, as Gatto suggests, the tale uses the metaphor of sexuality to depict the seductive nature of all knowledge, not just knowledge of the erotic.

As the story begins, wilmarth is an innocent, an uninitiated scholar living in a harmless world of folklore and mythology. As Peter Cannon has suggested, he "plays the role of ingenuous virgin while the beings who try to entice him into their cosmic harem act as the part of seducer" (92). The reader, who is more experienced in the ways of the world, can foresee the trouble that wilmarth is heading for; tension is maintained by the fact that the reader understands but cannot issue a warning to the protagonist.

Unlike the traditional seducer, the Fungi from Yuggoth offer not sex but knowledge, "a rich boon of knowledge and intellectual adventure which few mortals have ever shared" (DH 239). They symbolically offer wilmarth the opportunity to leave Eden and eat from the tree of knowledge, which is a far more dangerous prospect than mere sensuality. The sexual connotations and symbols merely act as the metaphor for this greater destructive potential.

For Lovecraft and his protagonists, knowledge offered a far more tempting and forbidden fruit than mere sexuality: 
To shake off the maddening and wearying limitations of time and space and natural law-to be linked with the vast outside -- to come close to the nighted and abysmal secrets of the infinite and the ultimate-- surely such a thing was worth the risk of one's life, soul, and sanity! (DH 243).

Wilmarth, despite his instinctive fear of this knowledge, becomes tempted as "a burning interest and curiosity" replaces his original dread. Both he and Akeley "will find any risks worth running for the sake of knowledge" (DH $219)$.

The nature of the forbidden knowledge, predictably enough, concerns the universe and man's lack of importance within the cosmos. Although he (mercifully) never learns all of the secrets of the universe, Wilmarth does gain forbidden knowledge of :

...the construction of ultimate infinity, the juxtaposition of dimensions, and the frightful position of our known cosmos of space and time in the unending chain of linked cosmos-atoms which makes up the super-cosmos of curves, angles, and material and semi-material electronic organization." ( $\mathrm{DH} 256$ )

This knowledge, per se, is not evil-- it is, after 
all, the ultimate quest of the scientist to understand the universe-- one cannot find evil in the inquiries of astronomer Stephen Hawking (author of A Brief History of re. From the Big Bang to Black Holes ), who has searched the edges of the universe for answers. Yet Hawking and other modern scientists, like Wilmarth, like Eve, are, according to Lovecraft, reaching for the forbidden fruit that may bring about destruction. And much of the knowledge they have uncovered about the origin and size of the universe is disquieting, indeed.

Wilmarth's new knowledge brings him perilously close to madness and death: "... never was an organic brain nearer to utter annihilation in the chaos that transcends form and force and symmetry", and, in fact, there are secrets that he dares not reveal to the reader. Yet even in the final analysis, wilmarth can never totally relinquish his quest for knowledge or his desire to share it with others. "It is, after all, a tremendous pity that I did not disobey Akeley and play the record for others-a tremendous pity, too, that all his letters were lost" ( $\mathrm{DH}$ 227 ).

Ironically, Wilmarth's narrative is an attempt to censor knowledge rather than share it, as he states that his disclosure of the events is a "warning about those farther Vermont hills." Much like the narrator of At The Mountains of Madness, Wilmarth hopes that his revelation will halt all further investigation of the matter. Yet, as 
Lovecraft-- and Wilmarth-- know only too well, the warning itself becomes a device of the "hermeneutic code," since man is always more attracted to that which is forbidden, and there is no reason to think that scholars who follow would not also take whatever risks are necessary in the pursuit of knowledge.

The textual code of self-censorship, and wilmarth's mixed feelings about it, effectively becomes a mechanism for increasing suspense in the tale. Even as the narrator reveals information, he skillfully holds things back, claiming that such things are too hideous ofr"forbidden" to be told. As we have seen in The Case of Charles Dexter Ward, knowledge cannot be censored, even if this censorship is desired. Thus, once the tale has been completed, of course, the reader has pieced the "forbidden" knowledge together, both within the story itself and through extrapolation with Lovecraft's other Mythos stories, which are all interconnected. Yet the reader, like wilmarth and other Lovecraft protagonists, gains satisfaction at having obtained this forbidden knowledge for himself-- and often obtaining it before the story's "hero" even realizes its significance. Lovecraft, like the whisperer in the darkness, does not shout his truths, but whispers them, knowing that $h$ is readers will make the connections and understand the tales.

Examining the connotative code of "The Whisperer in the Darkness" leads to several interesting observations. 
First, as Joshi has noted, the Fungi from Yuggoth are more "human" than most of Lovecraft's monsters. "They reveal certain fairly commonplace nefarious traits-- deceit, trickery, hatred, vengeance, even forgery... that are otherwise purely human" (Decline 87). Furthermore, they are not only mortal, but can be killed by purely conventional means (guns and floods) and are frightened of dogs. These creatures are capable of destroying the earth if they wanted to but seem to be prevented from doing so by their curiosity about mankind.

In the cosmic scheme of things, then, these aliens are of a much lower order than the Yog-Sothoth, the Elder Gods or the Old Ones. Yet even these "weaker" aliens greatly surpass humanity both in power and in knowledge. In addition, since they are "fungi" they are presumably lower on the evolutionary scale than man-- in other words, they have not yet evolved to their full potential. Even lower forms of life on other planets, then, dwarf human achievement.

The second connotative point of interest lies in the description of nature, and its contrast with civilization. As Joshi has noted, Lovecraft consistently treats nature as "some uncontrollable beast whose almost active resistance to human attempts to tame it is somehow sinister and even suggestive of some cosmic alienage" (Weird Tale 220). In virtually all of his fiction, Lovecraft's aliens inhabit remote, uncivilized parts of the earth-- "The Dunwich 
Horror", "The Colour Out of Space", At the Mountains of Madness, and "The Whisperer in the Darkness" are but a few good examples. Thus, nature is seen as a force of the cosmos rather than as a part of the earth, and these natural forces operate by their own rules rather than by the rules of man.

"The Whisperer in Darkness" affords an excellent opportunity to examine Lovecraft's concept of nature in some detail. With its setting in rural Vermont, the story contrasts nature in its elemental forms with man's feeble attempts to domesticate his surroundings. This contrast can best be seen in the image of the "lonely Akeley farmhouse" surrounded by the "wild domed hills of Vermont." The house is "about a century and a quarter old, and with a well-kept lawn and stone-bordered path leading up to a tastefully carved Georgian doorway" ( $\mathrm{DH} 222$ ). In order to remain free of encroaching nature, the house and its surroundings must be "well-kept" both by constant cutting and by a border of "whitewashed stones." Even as the stones and the constant lawn maintenance keeps nature at bay, the army of domesticated dogs is required to maintain civilization in the "wild and haunted hills."

Nature, on the other hand, resembles the Fungi from Yuggoth; it could just as easily "conquer the earth" if it so desired, a feat symbolized by the floods that destroyed both humans and the alien fungi which happened to be in nature's destructive path. It is portrayed as "wild", 
"crowded", and, interestingly enough "muttering"-- nature, like the Fungi, has secrets to tell.

Returning to the Eden theme, man, with his well-kept civilization, lives in an Eden of his own creation, a place where nature is kept well manicured in man's gardens and lawns. This Eden is surrounded by both the power and the mystery of nature, which threatens to destroy civilization, both with its physical potential (the floods, for example), and in the revelation of its secret knowledge about the universe. The Fungi, then, like many of Lovecraft's aliens, are merely the messengers of nature and of the cosmos. They signify the telling of the secrets rather than the actual secrets themselves. Nature represents the embodiment of the secrets of the universe-- understanding nature may result in an understanding of the frightful truths of the universe.

wilmarth, in effect, leaves the Eden of his civilization to listen to the whisper of nature and the tree of knowledge. This siren song of knowledge lures him like a seductress, and he metaphorically loses his virginity to Mother Nature as he learns her secrets. He abandons his study of folklore-- the "make believe"-- for the quest for the real knowledge of space and time, knowledge that depicts man as but a tiny and insignificant part of nature and the cosmos. This knowledge carries a price, both the the human ego and to human innocence. For once the knowledge is gained, Eden is lost, and 
civilization no longer remains the safe refuge it once was. Man is forever banished into the wild and haunting world of the unforgiving universe which as the power to destroy him and his creations at any time that it chooses.

Man's tragedy, according to Lovecraft, is that he is doomed to listen to the siren's song, that nature and evolution have equipped him with both the ability and the overwhelming desire to learn. For mankind, the acquisition of knowledge is worth any price. Even as man recognizes the destructive potential of studies in the areas of nuclear physics, genetics, and chemistry, he continues to pursue such research, and will alwanys continue to do so, regardless of the potential consequences.

"The Whisperer in Darkness" is not about censorship of pornography, but about the censorship of scientific research and study. Even as Lovecraft-- and perhaps the world-- realizes the destructive potential of research into nuclear weapons, for example, he also recognizes the utter impossibility of halting such research. The quest for knowledge is simply too powerful, and even a warning to stop would only make the acquisition of such knowledge more desirable. 


\section{5. "The Shadow Out of Time": Out of the Shadows}

"The Shadow out of Time," the last story in this analysis, shows Lovecraft at his full maturity and in complete control of his material. While his major themes of cosmic horror, man's insignificance in the universe, and the destructive nature of knowledge remained essentially the same throughout his career, "The shadow out of Time" does, in many ways, crystalize these themes using the metaphor of writing and authorship and the symbolic opposition of dreams and reality. In this study of fantasy and realism, Lovecraft essentially brings horror out of the shadows and into the harsh light of realism.

Strictly from a plot standpoint, "The shadow out of Time" is a masterpiece of suspense, as Lovecraft successfully delays his conclusion until the final lines of the story. As Joshi has observed, "Peaslee's discovery of the document he must have written $150,000,000$ years ago is perhaps the most mind-shattering moment in all of literature" (Weird Tale 208). Although Peaslee makes his discovery on page 427-28 (DH), its nature is not fully revealed to the reader until page 433 . Despite the 
narrator's statement that "no reader can have failed to guess it", this conclusion still comes as a shock to the senses, leaving reverberations in the reader's mind long after the story has been finished.

Much of the effectiveness of this ending comes from Lovecraft's technique of misdirection. Once the discovery is made, the reader, of course, craves to know the details. Instead of telling the secret immediately, however, Lovecraft cleverly introduces a second source of tension as the narrator struggles to escape from the underground cavern and realizes the possibility that alien life forms may still be present. This concrete element of danger builds suspense in a different direction, allowing the author to file away his terrible secret until the very end. Revealing the mystery after the narrator has escaped from the crypt and is safe allows the full impact of the discovery to be experienced.

While "The Shadow out of Time" effectively handles the theme of forbidden knowledge and its destructive potential, this story does add some subtle differences to the theme. Peaslee, despite his five-year amnesia and fears of madness, seems to be one of Lovecraft's more "normal" narrator's. As a professor of economics, he was, no doubt, a scholar-- yet he is depicted primarily in a teaching role before his amnesia, a role where he interacted with others. He, too, is one of the few narrators to have a family, and to have the companionship of a devoted son who supports him 
through the most difficult times. This is uncharacteristic of Lovecraft's "typical" narrators, who tend to be lone scholars with little or no outside social contacts.

Peaslee's normalcy, if you will, gives a different perspective to the search for truth. This narrator is a passive receptacle for horrible truths, unlike Robert Blake and Herbert West, who actively pursue the dark side of knowledge. Peaslee is more the prototype for the modern horror story, the everyday man who finds himself in extraordinary situations, a theme made popular by Rod Serling's The Twilight Zone (1959-64).

The story begins, chronologically speaking, with the narrator minding his own business, teaching an economics class. Even his field of study, economics, involves the realistic, the mundane, and the practical, rather than studies such as astronomy and philosophy that question the nature of truth and reality. Through no fault or action of his own, Peaslee becomes involved in a horror beyond his control, and, without seeking knowledge, is given answers to the most forbidden questions concerning the universe. Knowledge seeks him rather than the other way around.

Peaslee's acquisition of knowledge serves as a metaphor for the human race, which is destined to secure knowledge that has destructive potential, both psychologically and technologically. As Peaslee moves through the symbolic labyrinth of the cavern, he experiences a "driving fatality" (417) as he seems "to move 
almost automatically, as if in the clutch of some compelling fate" (415) towards his "fated destination" (421). Man, like Peaslee whose "madness drove me on" (419), is destined to learn. His compulsive, almost insane need to know and discover is his inescapable fate, a fate that, Lovecraft realizes, has destructive potential.

Yet, "The Shadow out of Time" also shows an ambivalence about curiosity and recognizes that man's obsession with knowledge has a constructive side to it, which comes into conflict with the destructive. As Peaslee attempts to learn about the nature of his amnesia, his doctors "heartily endorsed [it] as correct according to the best psychological principles" (379). Lovecraft recognizes that "... to such [keen] minds the unveiling of hidden mysteries of the earth... forms always, despite the abysmal horror often unveiled, the supreme experience of life" (387).

Peaslee himself expresses his ambivalence about what he has learned. While he claims that "... its realism was so hideous" (368), he also records his dreams and experiences and says that his account "ought to be published" (403). Although he defends his account as a warning to keep others from unlocking the secrets which have again become hidden, the narrator knows full well that such a warning will only encourage further exploration rather than discourage it. He has already learned this lesson when he tries to halt further exploration during his 
expedition: "Naturally, no one paid any attention to my new wishes" (411). What reason has he to believe that his wishes would be respected now?

It is obvious that knowledge is destined to be found, with no regard to the consequences-- Peaslee's plea to censor such studies only makes them more attractive. "If the laws of the universe are kind, they will never be found," he says, referring to the books of the great race. Yet, since he has already seen the laws of the universe he knows they are not kind, and nothing he can say or do will keep the knowledge secret. In some perverse corner of Peaslee's mind he welcomes the acquisition of knowledge, knowledge which he himself "both hoped and feared to find" (425). In leaving his account to his son to either destroy or share with the world, he knows his story will be published, despite his possible (and probably half-hearted) protests. His son, also a seeker of knowledge, would no sooner bury his father's story than he would agree to his wishes to give up digging in the Australian desert. Indeed, examining the story from the point of view of this textual code proves that the account was published, thus its existence as a readable text.

Another major theme of "The shadow out of Time" concerns the act of writing itself. This story, more than any in the Lovecraft canon, privileges the importance of the written word. To Lovecraft and his narrator, the written word is concrete, hence the desire to "have the 
revelation in written form." Soon after his strange dreams begin and "grow in vividness and concreteness" (377) the narrator begins to record them, and actually publishes his experiences in a psychological journal. And, interestingly enough, the great race, whose very existence was based upon the intellect, carefully and meticulously record their extensive knowledge through writing and securely store this accumulated knowledge in their underground library. While Lovecraft laments that "words can convey only fractionally" (417) what he wishes to relate, he seems to regard this as a deficiency on his own part, for the "greatest race of all" (385) regarded the written word as the ultimate source of all knowledge.

While Lovecraft cannot be faulted for failing to predict the future existence of computer data banks as storage centers for knowledge, his final image, "... the letters of our own familiar alphabet, spelling out the words of the English language in my own handwriting" (433), symbolizes the power of the written word in even its more primitive, handwritten form. These handwritten words have existed for $150 \mathrm{million}$ years, outliving the rise and fall of empires and the extinction of entire species. This image of writing demonstrates not only its remarkable power of endurance, but its power to record and replay wisdom and truth, even though such truth might not be pleasant to behold.

Lovecraft sees man as not only destined to learn, but 
destined to share that learning through the written word, even as Lovecraft himself has shared unpleasant knowledge through both his fictional writings and in his extensive correspondence. As Cannon has said, the final image of English handwriting:

... captures the essence of the man who, never having had his work collected in book form, daily delighted in putting fountain pen to paper, typically either to record his peculiar personal vision in letters or to transfer it in fiction, in his distinctive spidery script. For Lovecraft, such an exercise, coupled with the pure acquisition of knowledge, was among the highest of human endeavors." (110)

Lovecraft, like Peaslee, learned a number of unpleasant truths and, with "driving fatality" recorded these truths in his stories. While, like Peaslee, he, too believed that his record should be published as a book, he unwittingly shared the fate of his narrator and left his works for someone else to publish. It is in these works that Lovecraft moved truth into the shadows of horror fiction, into the realm of dreams and the fantastic. Yet as we have seen in "The Shadow out of Time," dreams can grow concrete through the use of the written words. Understanding the reality disguised within these dreams, within these fictions, brings truth out of the shadows; 
despite the "abysmal horror often unveiled" this forms what Lovecraft saw as "the supreme experience of life." 


\section{1}

CONCLUSION 


\section{CONCLUSION}

Although academic critics tend to dismiss H.P. Lovecraft as just a science fiction writer, a detailed analysis of his work demonstrates that his fiction goes beyond the mere hack work written by many of his contemporaries for the pulp magazines of the time. While Lovecraft certainly did have a major influence on the development of the science fiction and horror genres, it is obvious that Lovecraft does, indeed, have something significant to say. His work symbolically reflects his own philosophy and view of the universe, and does so in a distinctive, appropriate, and unique style.

In attempting to go beyond the work done by the capable amateurs who write for the horror, science fiction and fan presses, I have endeavored to discover the essence of Lovecraft through the use of established critical theory and literary techniques, thereby making my conclusions more acceptable to the academic community, while also demonstrating the importance of critical theory to the average Lovecraft fan. The application of scholarly technique to Lovecraft studies represents an important first step in bringing Lovecraft out of the shadows and 
into the light of mainstream literature. Critical theorv is an essential tool in objectively determining Lovecraft's place in American Iiterature and, I believe, a powerful instrument with which to gauge his strength as a writer. LOVECRAFT'S INFLUENCE ON HORROR

The influence of H.P. Lovecraft on horror cannot be denied. As King has acknowledged: "it is his shadow, so long and gaunt, and his eyes, so dark and puritanical, which overlie almost all of the important horror fiction that has come since" (102). His "experimental fusion of [science fiction] with fantasy" made it common for authors to work in both fields (Daniels 148), and set the stage for the scientific horror stories that became so popular in the $1950^{\prime}$ s and continue even until this day.

By taking horror out of the traditional haunted house and placing it in realistic context, Lovecraft redefined a dying genre, making it possible for modern authors to make lucrative careers from the tale of terror. As we have seen in "The Shunned House," Lovecraft realized that traditional Gothic horror could no longer inspire true fear in the modern world; his new brand of cosmic horror responded to the fears of the space age before sputnik was even launched.

Lovecraft remains popular as a writer of the weird tale, despite the lack of characterization and antiguated prose that would seemingly make his work less appealing to a modern audience. His books continue to be reprinted, 
both in hardcover and mass market paperback, and his stories are still widely anthologized.

The key to Lovecraft's success as a horror writer obviously lies in his ability to create a sense of dread and fear within the reader. As we have seen, he accomplishes this in several ways. From a technical point of view, we have seen how he uses a number of narrative devices to create and maintain suspense throughout the narrative. Examining the hermeneutic code in relation to his tales has shown that Lovecraft was a master at creating enigmas and delaying their resolution until the last possible moment. More importantly, perhaps, he allowed the reader to discover the answers to these enigmas for himself, thus making the reader an actual participant in the story. In "The Call of Cthulhu" the reader experiences the peril of discovery along with the narrator, and in The Case of Charles Dexter Ward the reader becomes a historian who "discovers too much."

While Lovecraft's fiction lacks strong human characterization, the atmosphere and the "monster" or horror often becomes a well-developed character. From the point of view of popular culture, villains are much more interesting (and often more popular) than heroes, and this is even more true in horror fiction (while Count Dracula is a household word, only a Bram Stoker scholar can remember the name of the hero who defeated him). Lovecraft, with his pantheon of Cthulhu creatures, has created an array of 
villains that are not only unforgettable, but scientifically possible. Furthermore, he has created an entire mythology around his creations, a twentieth-century scientific mythology that has, in many ways, replaced the ghost and goblin legends of the past. His mythical book, The Necronomican, has become a legend in its own right, being "such a successful hoax that several collectors have offered astronomical prices for a copy" (Daniels 120).

Above all, I believe Lovecraft's success as a horror writer lies in his ability to touch the collective unconscious, to subconsciously hit upon the things that frighten us most. While these fears may be symbolized by the Cthulhu monsters, in reality they are much more profound, touching upon man's own fear of his insignificance, a philosophy that Lovecraft felt so deeply and expressed so well. Much of this ability to touch the subconscious lies in Lovecraft's ability to hint at horror without spelling it out in graphic detail, as is the current trend in horror films. Recognizing the fact that naming the horror gives the reader power over it, thus removing some of the fear, Lovecraft chose to leave much of the detail of his creations to the imagination. The unexplainable and impossible color of the alien in "The Colour out of space," for example, creates a much greater sense of dread and terror than does a "splatterpunk" horror film with chainsaws and body parts. The latter may evoke what stephen King terms "the gross-out," but misses the 
mark of terror by a wide margin. LOVECRAFT'S USE OF HORROR AS METAPHOR

While Lovecraft, by his own admission, wrote the "weird tale," his stories transcend the boundaries of horror and science fiction by using the fantastic as a device to speak about $\mathrm{life}$ and the human condition. His fantastic stories, like shadows, are created by shining light upon man's concrete fears. These fears, unlike the ghosts and goblins of the past, are quite real and can all be represented by the frightful and destructive potential of knowledge. On a psychological level, knowing too much about oneself can be the ultimate horror, as we have seen in "The Outsider." Knowing too much about one's ancestors can be damaging, as we have seen in "The Rats in the Walls" and other stories. The pursuit of historical knowledge can lead to its own problems, as in The Case of Charles Dexter Ward. Archeology can unearth terrors ("The Shadow out of Time") and too much scientific knowledge results in horrors of a different sort ("From Beyond").

According to Lovecraft, all of this knowledge points to a single truth, a terrible truth from the human point of view: namely, that mankind is but a tiny insignificant speck, without hope and without meaning. The more we learn, Lovecraft says, the smaller we become. Least one think this is not a painful truth to learn, a brief look at the initial reaction to the theories of visionaries ranging from Galileo to Darwin to Freud should offer a convincing 
argument otherwise.

The ultimate horror, perhaps, lies in the fact that man will not only continue to learn terrible truths about himself and his universe, but is in fact destined to do so. Man, by his very nature, has evolved so that he must learn; his curiosity is as strong an instinct as the desire for food and shelter. Furthermore, any efforts to censor knowledge once it is obtained are doomed to failure.

Lovecraft uses the weird tale as a metaphor for knowledge. Even as we are repulsed by horror, so too are we perversely attracted to it, just as we are also simultaneously attracted and repulsed by the forbidden aspects of knowledge. Lovecraft recognized that the tale of terror has existed as an important part of human folklore since the dawn of civilization, and that the emotion of fear symbolizes the dual nature of knowledge. The unknown, of course, is the primeval fear; man has attempted to ease this fear through the creation of mythology. The systematic and scientific search for truth often upsets these myths, however, and replaces them with unpleasant truths-- such as the theories of Charles Darwin, for example, which have (and continue to) upset belief systems. Lovecraft fictionally replaces traditional mythology with a mythology of fear based upon scientific principles of the space age. LOVECRAFT'S PLACE IN AMERICAN LITERATURE

Although H.P. Lovecraft has been compared to Poe, the 
fashions and biases of twentieth century criticism have thus far kept him from inclusion in the canon of American literature. Indeed, since Lovecraft's work runs counter to the development of twentieth century literature, it is difficult if not impossible to compare him to his great literary contemporaries, Hemingway, Faulkner and Fitzgerald. While "mainstream" literature developed in a way that emphasized realism along with complex psychological themes and characterization, Lovecraft pursued an entirely different sort of artistic development, a mode that expanded outwards into the universe rather than internally into the human mind. While writers such as Faulkner and Joyce focused a microscope on the individual, Lovecraft used a telescope, which he trained upon distant galaxies. Although twentieth century critics privilege the microscopic examination of the human specimen, Lovecraft's method of observation is equally as valid.

Largely because of these twentieth century biases, as well as the overall bias against the science fiction genre as a whole, Lovecraft has not fared well with the critics, who have been quick to point out his shortcomings. Much like the stories of his predecessor, Edgar Allan Poe, Lovecraft's fiction is uneven, and one would be mistaken in viewing his inferior stories as representative of his work. When he is at his best, as in "Pickman's Model", "The Shadow out of Time", or "The Colour out of Space", Lovecraft uses horror to express a number of complex ideas 
and creates an exquisite sense of dread that lingers long after the story is done. These stories "make us feel the size of the universe we hang suspended in, and suggest shadowy forces that could destroy us all if they so much grunted in their sleep" (King 72). Yet he just as often falls short, as in "The Shunned House", for example, where the evil monster does not live up to expectations and is rather easily destroyed.

Much of Lovecraft's problem in his weaker stories stems from his desire to capture the ultimate emotion of fear, to reach the collective unconscious of human terror, and to settle for nothing less. This is an incredibly difficult feat to accomplish and, to Lovecraft's credit, he was able to come very close to capturing this elemental fear in a number of stories, including "The Colour out of Space." Yet, unlike most horror writers he was unwilling to compromise, unwilling to settle for second best. As Stephen King has said, there are three elements of horror: terror, horror, and what he terms the "gross-out." According to king, terror is the most difficult to achieve, and the gross-out the easiest. While King admits that he will settle for horror or the gross-out if he cannot achieve terror, Lovecraft would accept nothing less than terror. Thus, when he falls short of his mark, his stories suffer tremendously. In some cases, he seems to try too hard to hit fear through the collective unconscious, leaving too much to the reader's imagination and the 
resulting tale seems lame and unfulfilling.

In even his best stories, Lovecraft's style runs against the grain of the developmental path of twentieth century literature, and critics have incorrectly perceived this difference in style as a regression and a major flaw in his work. While this style does not conform to the fashion privileged by modern critics, it is actually most appropriate for the type of tale that Lovecraft tells and reflects the different mode of storytelling that Lovecraft has chosen to pursue.

As we have seen, Lovecraft did not consider character development an important part of his fiction, and this lack of character development effectively reinforces his theme of human insignificance. Yet while Lovecraft was writing about ideas and using cosmic forces as his main characters, English and American literature as a whole was becoming increasingly concerned with characterization. The major literary figures of the time created realistic and memorable characters like Jay Gatsby and Nick Adams and explored the human psyche through the eyes of idiots (Benji Compsen) geniuses (Stephen Dedalus) and the entire pantheon of Babbits, Joads, and Pilars who lived between these intellectual poles. Even though such interesting and individual characters would have negated Lovecraft's major themes, this lack of characterization has been mistakenly perceived as a flaw in his work because it does not conform to the twentieth century vision of what a story should be. 
Almost as disturbing to modern critics is Lovecraft's propensity towards an eighteenth century prose style. His archaic spelling, overuse of adjectives, and general antiquated style have also been incorrectly perceived as flaws because this style deviates from the path that twentieth century literature follows. While Hemingway was inventing the lean, simple noun-verb style that has become the mainstay of popular literature, and Joyce and Faulkner were experimenting stream of consciousness and unorthodox point of view, Lovecraft seemed to have regressed to a style that had long since gone out of fashion.

Yet, like his lack of characterization, Lovecraft's antiquated style is appropriate and logical for the stories he tells. As we have seen in "Pickman's Model" and other stories, Lovecraft felt that the past was a means to discover knowledge and truth. Therefore, it is only natural that he reveal truth through an ancient style; his return to the eighteenth century structurally reflects his meaning and reinforces his thematic content.

Not only does his antiquated style mirror his major themes, but it is also an appropriate vehicle for his narrators, who are, for the most part, scholars who live in the past. Having Charles Dexter Ward speak with the vernacular of a Hemingway character would be as inappropriate as having Tarzan speak with a Brooklyn accent. The eighteenth century voice is appropriate to Lovecraft's characters and narrators and shows their 
connection with the past and, in many ways, their desire to return to older and simpler times. While it may not make them "realistic" in twentieth century terms, it does make them believable within the context of their own small and specialized world. Furthermore, this style also reflects Lovecraft's own yearning for the past as a means of escaping an uncertain future. "I am certainly a relic of the 18th century" he wrote (SL I 11), and admitted:

of the crimes and drunken hilarity and inane amusements of modern urban 1 ife nothing captivates my fancy. Set the calendar back a century and bring in some event involving old Nantucket or Providence or Charleston life, and my interest grows..." ( SL V 25)

Finally, and perhaps most importantly, Lovecraft fails with the critics because of the type of story that he wrote-- the "weird tale." With the possible exception of Poe, writers of horror and science fiction have never been accepted into the mainstream academic community. When a work of horror is accepted, as in Stevenson's Dr. Jekyll and Mr. Hyde or Shelley's Frankenstein, for example, it is considered a mainstream allegorical work that just happens to have elements of horror. Despite the fact that horror forms an important part of literature from its very beginnings (The Odyssey, Beowulf, and MacBeth all contain elements of terror), horror and science fiction have not 
been embraced by mainstream critics.

As Hume has observed, literature has used the fantastic as a device to express truth until the twentieth century, which, by privileging "science and reason, objectivity and observation" (39) has resulted in a predominance of realism in literature (29-40). Yet, Hume acknowledges, "To answer questions about the nature of the universe without using fantasy is practically impossible" (121). The sudden popularity of science fiction and horror in the twentieth century is perhaps a vehicle to overcome the shortcomings of realism as a means to truth. Yet, since critics have favored realism over fantasy, these "fantastic" works have not been accepted into the literary canon.

The fact that Lovecraft wrote for the cheap pulp magazines such as Weird Tales has not helped his reputation. Yet these pulps were the only journals of the time that would publish the type of fiction that Lovecraft produced. Mass market paperbacks were still unheard of at the time, and the "mainstream" magazines were not interested in publishing horror or science fiction. IN DEFENSE OF H.P. LOVECRAFT

While I do not advocate that The Case of Charles Dexter Ward should replace A Farewell to Arms on the freshman reading 1 ist, I believe that Lovecraft does deserve a place in the canon of American literature between 1900 and 1940. While he has been perceived as regressive 
because of the narrow-minded twentieth century privileging of realism, characterization, and introspective themes, Lovecraft's fiction actually represents a progressive view of the realism that defines the literature of this time. While Lovecraft may write in a mode that cuts against the grain of the American literary canon, he does have something important to say about the human condition and mankind's relationship to the universe. His overall theme of cosmic insignificance cannot be told in the traditional, realistic way, but requires elements of fantasy, horror and imagination. This use of fantasy results in a form of super-realism, since he gives a logical and scientific basis to his fantastic elements, and since even his most fantastic stories do point out some very realistic and disturbing themes.

In order to accept Lovecraft on equal terms with his peers, the critic must broaden his scope, must, in effect, trade in his microscope for the telescope, and learn to look outward at different things and different kinds of artistic accomplishment. Since Lovecraft chose to privilege different elements in his writing, he cannot be compared to his contemporaries if he is expected to play by their rules. Although he, in fact, played the same game, he operated by an entirely different set of standards, standards that allowed him to "go beyond" the small world and explore the cosmic naturalism of the universe. Although no critical theory can be entirely free from 
bias, a structuralist method attempts to examine texts scientifically, without being concerned with what is fashionable. Since it has traditionally examined science fiction, horror, and other "unorthodox" genres in the same unbiased manner as that of mainstream literature, it is, perhaps, the most appropriate way in which to study the work of H.P. Lovecraft.

A structuralist analysis of his work demonstrates that Lovecraft was a master of narrative technique; his stories show a strong union of style, structure, and substance and his method of telling the story is a logical development of theme and meaning, even though this method may run contrary to modern literary "fashion." In relating his meaning, Lovecraft developed a unique and distinctive style-- a style that (like that of Poe) has since been copied by a generation of budding imitators, but seldom copied well. H.P. Lovecraft, like Janus, simultaneously looked to the past and to the future, and saw disturbing truth in both directions. For Lovecraft the past offered its own brand of truth, in history, archeology, genealogy, literature and folklore. His antiquated style and nostalgic prose reflects this past and symbolizes the meaning antiquity can give to the modern world. Many of his scholars, historians and archeologists, symbolize this search for truth by looking backward.

On the other hand, the future offers a truth of its own, a disturbing vision produced by science and 
technology. Lovecraft's scientific realism as a means of understanding the fantastic symbolizes this view, as does his scientist narrators, Herbert West and others. This view of the future is equally if not more disturbing than the truth offered by the past.

Yet for Lovecraft, the ultimate truth could only be seen by looking in both directions at once, by combining folklore with science, history with astronomy, and dreams with reality. It is this "inability of the human mind to correlate all its contents" which keeps mankind in darkness. Lovecraft, by looking both to the past and to the future accomplished the "piecing together of dissociated knowledge" and opened up "terrifying vistas of reality" that have, in many ways, gone beyond the tame truths expressed by the naturalists. It is this ability to go "beyond", to show the "pets" that "are not pretty" that has made Lovecraft's work so popular and so unforgettable. Regardless of whether or not Lovecraft is ever accepted by the critics, he will continue to be embraced by new generations of readers who have given him his own unofficial place both in horror and science fiction and in American literature. 


\section{Bibliography}

Barthes, Roland. $\mathrm{S} / \mathrm{Z}$. Trans. Richard Miller. New York: Hill and Wang, 1974.

-.-. "Textual Analysis of Poe's 'Valdemar'," Untying the Text. Ed. Robert Young. Boston, London, and Henley: Routledge \& Kegan Paul, 1981.

Bloch, Robert. "Author's Afterword: Will the Real Robert Bloch Please Stand Up?" The Best of Robert Bloch. New York: Del Rey, 1977.

Botkin, B.A. A Treasury of New England Folklore. New York: Bonanza, 1965.

Burleson, Donarld R. Lovecraft: Disturbing the Universe. Lexington: University of Kentucky Press, 1990.

Burleson, Mollie L. "The Outsider: A Woman?" Lovecraft Studies 22/23, (Fall, 1990): 22-23.

Cannon, Peter. H.P. Lovecraft. Boston: Twayne, 1989.

Clarke, Arthur C. The Nine Billion Names of God. New York, Signet, 1974 .

Daniels, Les. Living in Fear: a History of Horror in the Mass Media. New York: Scribners, 1975

De Camp, L. Sprague. Lovecraft: A Biography. New York: Doubleday, 1975.

De Saussure, Ferdinand. Course in General Linguistics. trans. Wade Baskin. New York: McGraw-Hill, 1966.

Faig, Kenneth w. The Parents of H.P. Lovecraft. West Warwick: Necronomican Press, 1990.

Fulwiler, William. "Reflections on 'The Outsider'". Lovecraft Studies 2 (Spring, 1980): $3-4$.

Gafford, Sam. "'The Shadow over Innsmouth': Lovecraft's Melting Pot". Lovecraft Studies 24 (Spring, 1991): 6-13.

Gatto, John T. The Major Works of H.P. Lovecraft: a Critical Commentary. New York: Monarch, 1977.

Genette, Gerard. Figures of Literary Discourse. trans. Alan Shericlar. New York: Columbia University Press, 1982 . 
--. Narrative Discourse, Trans. Jane E. Lewin. Ithica: Cornell University Press, 1982.

Greimas, A.J. "The Play of Semiotic Constraints". Yale French Studies, No. 41, 1968: 86-105.

Hume, Kathryn. Fantasy and Mimesis. New York: Methuen, 1984 .

Jameson, Fredric. The Prison-House of Language. Princeton: Princeton University Press, 1972.

Joshi, S.T. "Autobiography in Lovecraft"

Necon Stories. ed. The NECON Committee.

Providence: Three Bobs Press, 1990.

--. H.P. Lovecraft: The Decline of the West . Mercer Island, WA: Starmount, 1990.

-- The Weird Tale. Austin: University of Texas Press, 1990.

King, Stephen. Danse Macabre, New York: Everest House, 1981 .

Leiber, Fritz. "A Literary Copernicus".

H.P. Lovecraft: Four Decades of Criticism. ed. S.T. Joshi. Athens, OH: Ohio University Press, 1980 .

Levi-Strauss, Claude. Structural Anthropology Vol. II. trans. M. Layton. New York: Basic Books, 1976.

Levy, Maurice. Lovecraft: A Study in the Fantastic. trans. S.T. Joshi. Detroit: Wayne State University Press, 1988 .

Lovecraft, H.P. At the Mountains of Madness and Other Novels, Rev. ed. S.T. Joshi, Sauk City, WI: Arkham House, 1985.

-- The Dunwich Horror and Others. Rev. ed. S.T. Joshi. Sauk City, WI: Arkham House, 1984.

--. Dagon and Other Macabre Tales. Rev. ed. S.T. Joshi. Sauk City, WI: Arkham House, 1986.

--. In Defense of Dagon. ed. S.T. Joshi. West Warwick: Necronomican Press, 1985.

--. Selected Letters Volumes I, II, III., IV, V. ed. August Derleth and Donald Wandrei, Sauk City: Arkham House, 1971 . 
Lynn, Lawrence $R$. The Cthulhu Mythos in the Writings of H.P. Lovecraft. Unpublished Master's Thesis, University of Rhode Island, 1971.

Penzoldt, Peter. "The Supernatural in Fiction". H.P. Lovecraft: Four Decades of Criticism. ed. S.T. Joshi. Athens, OH: Ohio University Press, 1980.

Petersen, Sandy. S. Petersen's Field Guide to Cthulhu Monsters. Albany CA: Chaosium, 1988 .

Price, Robert. "What is the Cthulhu Mythos?" Lovecraft Studies 14: 15-17.

Propp, Vladimir. Morphology of the Folk Tale. trans. Laurence Scott. Austin: University of Texas Press, 1984 .

Scholes, Robert. Semiotics and Interpretation. New Haven: Yale University Press, 1982.

-.-. Structural Fabulation: An Essay on Fiction of the Future. Notre Dame: University of Notre Dame Press, 1975.

---. Structuralism in Literature. New Haven: Yale University Press, 1974.

Tierney, Richard. "The Derleth Mythos", Discovering H.P. Lovecraft. ed, Darrell

Schweitzer. Mercer Island, WA: Starmount, 1987.

Todorov, Tzvetan The Fantastic: a Structural Approach to a Literary Genre. Cleveland:

The Press of Case Western University, 1973.

--. Poetics of Prose. Ithica: Cornell University Press, 1977.

St. Armand, Barton, L. "Facts in the Case of H.P. Lovecraft", H.P. Lovecraft: Four Decades of Criticism. ed. S.T. Joshi. Athens, OH: Ohio University Press, 1980.

Wedeck, Harry E. and Baskin, Wade. Dictionary of Spiritualism. New York: Philosophical Library, 1971.

Wilson, Edmund. "Tales of the Marvellous and the Ridiculous", H.P. Lovecraft: Four Decades of Criticism. ed. S.T. Joshi. Athens, OH: Ohio University press, 1980. 
Yanat, Kamal. The French Response to the Works of H.P. Lovecraft: an Introduction and Bibliography (1954-1984). Unpublished Master's Thesis, University of Rhode Island, 1988. 